\title{
Jorge Silva Melo: um percurso traçado entre linhagens e heranças
}

MARIA JOÃO BRILHANTE, EUNICE TUDELA DE AZEVEDO, ANA CAMPOS E TERESA FARIA

Jorge Silva Melo conta já com quase cinco décadas de actividade entre o teatro, o cinema e a escrita. Aos dezoito anos, já escrevia para o Diário de Lisboa. Foi, entre tantas outras coisas, conselheiro cinematográfico de figuras maiores da cultura portuguesa contemporânea, assistente de realização de cineastas de referência, fundador da Cornucópia, estagiário de Peter Stein e Giorgio Strehler, actor de Jean Jourdheuil e motor de uma das mais importantes renovações do teatro português: os Artistas Unidos (AU). Passou pela Faculdade de Letras da Universidade de Lisboa e pela London School of Film Technique, mas a sua formação cultural e artística foi feita na cidade de Lisboa - que o viu nascer, crescer e partir para depois regressar -, nos cafés, nas livrarias, nos cinemas e nos teatros. Foi nos bastidores do Teatro da Politécnica, que agora ocupa com a companhia por ele fundada, que evocámos as memórias desse percurso pelo universo cultural que o formou e no qual participou activamente tanto na cena teatral como na cinematográfica. Mas não ficou de fora desta conversa a importância da escrita, que iniciou cedo como crítico, mais tarde como argumentista e como autor de textos levados à cena, nem a situação actual de quem faz teatro fora das instituições do Estado. Tudo isto com a cidade como pano de fundo, a cidade que se transforma e onde é cada vez mais difícil viver.

Comecemos pela formação: a formação informal, digamos assim; a da infância nas Amoreiras, do contexto de diversidade cultural proporcionado pela tua irmã e os seus amigos, a das pessoas com quem te cruzaste na juventude.

Até aos quinze anos, a minha formação foi, sobretudo, não escolar. Andei num colégio horrível, atroz, onde o professor de francês não sabia francês. Punha o linguafone. Era o Externato Marista de Lisboa. Toda a minha formação foi contra a escola e fora da escola. Ia ao teatro a que a minha irmã me levava. O primeiro espectáculo que me lembro de ter visto foi, no Tivoli, o Pega Fogo, de Jules Renard, com Cacilda Becker, espectáculo dirigido por Zelimsky que assinala o início do teatro moderno brasileiro. 
Ia aos concertos de música clássica com a minha irmã. Não ia tanto ao cinema, os filmes eram para dezassete anos, mas a minha irmã, que era sócia do CCC [Cineclube Católico], trazia-me os programas para casa, que eu devorava. Foi toda uma educação fora do âmbito escolar, onde nada disto existia, que aconteceu através da minha irmã e do grupo de católicos que frequentavam a minha casa. A minha irmã é doze anos mais velha e, quando ela entrou para a faculdade, eu entrei para a escola primária, mas foi como se tivesse feito a faculdade com ela, porque quem ia lá a casa eram os seus amigos. Através dela comecei a frequentar algumas sessões estranhas de iniciação ao cinema, organizadas pelo Bénard [da Costa], pelo Duarte Nuno Simões, pelo Alberto Vaz da Silva, pelos católicos. O resto era leitura, muito à imitação da minha irmã, muita literatura social. Ela estava muito empenhada nas causas da libertação das colónias, o que me fez escrever, quando tinha dezoito anos ou coisa parecida, um artigo sobre a poesia africana de expressão portuguesa, que foi proibido pela censura. Mas ganhei um prémio com esse artigo, que me permitiu ir a Paris. Eu escrevia para o suplemento juvenil do Diário de Lisboa do [Mário] Castrim.

O Colégio Marista era mesmo muito fechado. Pedi aos meus pais: «Estou farto deste colégio, quero ir para o Liceu Camões», porque ouvia falar dos grandes professores que lá havia: Mário Dionísio, Bénard, Fernando Belo... E tive-os como professores e, inclusivamente, tive a minha irmã. As aulas de Mário Dionísio foram centrais para tudo. Pela capacidade de análise, de explicação, de clareza de raciocínio. Foi como se tivesse vivido em França durante aquelas manhãs em que tinha aulas, quatro vezes por semana, de Português. Foi uma espécie de iniciação à literatura portuguesa absolutamente genial, como nunca mais tive. Através dos livros de Mário Dionísio, que eu lia fora das aulas, continuei com o ensinamento fora do contexto escolar. Através deles, começo a interessar-me pela pintura - lendo A Paleta e o Mundo e outros ensaios dele - e por alguma literatura socialmente empenhada, digamos.

O cinema, que o meu pai me ensinava - ele tinha sido um grande cinéfilo em novo, tinha mesmo chegado a acompanhar filmes mudos ao piano, creio que no cinema actualmente chamado Ideal--, continuou a ser a formação principal. Uma herança do meu pai, com quem falava; mas, para aí aos oito ou nove anos, fui eu que comecei a escolher os filmes que os meus pais viam ao domingo. Eu é que lhes dizia o que é que tinham de ir ver e só me enganei num, de que eles não gostaram. Não gostaram do Quanto mais Quente melhor, de Billy Wilder! Eu não podia ver, porque 
aquilo era mais que para adultos. Gostavam mais de dramas. O cinema vem daí, dos programas do CCC e do João Bénard, então professor no Liceu Camões. O teatro continuava a existir, mas não o teatro normal. $\mathrm{O}$ que eu ia ver era quando o TEP [Teatro Experimental do Porto] vinha a Lisboa ou quando havia os festivais internacionais de teatro da Casa da Imprensa, no Império. Era o teatro, digamos... da oposição.

\section{Mas porque tu sabias, de alguma maneira, que isso é que merecia ser visto?}

Era o teatro que a minha irmã frequentava. Vi muito pouco as companhias «normais». Ao Trindade, nunca ia, a minha irmã dizia que era mau. A companhia da Amélia, vi para aí duas vezes quando era adolescente. Até porque a maior parte dos espectáculos eram para maiores de dezassete anos, e eu tinha doze, treze, catorze. Vi os grandes espectáculos, o Diálogo das Carmelitas [1959], o Processo de Jesus [1958], da Companhia Rey Colaço-Robles Monteiro, mas aquilo não me atraía particularmente. Em contrapartida, não podia perder as vindas do TEP a Lisboa, assim como algum teatro estrangeiro. O Annonce faite à Marie, de Claudel, com a Daniele Delorme, no São Luiz. Ou o Ralph Richardson nos espectáculos de Shakespeare [O Mercador de Veneza e Sonho de Uma Noite de Verão, 1964], que vieram ao Tivoli.

Depois, quando entro para a faculdade, as aulas interessam-me muito pouco, excepto as de um professor absolutamente genial, o padre Manuel Antunes, que foi, com Mário Dionísio, um grande formador do pensamento. Ajudou-me a pensar não tanto a matéria que tinha de dar (que dava maravilhosamente), como a maneira de expor a matéria, como o Mário Dionísio. A forma de atacar a aula e de a organizar era absolutamente fascinante; era o reino da composição, qualquer que fosse o assunto. $\mathrm{O}$ padre Manuel Antunes era genial nisso. $\mathrm{O}$ resto interessou-me muito pouco. Mas interessaram-me os colegas. Eu tinha saído duma escola católica e no Liceu Camões só estive dois anos, criei poucos amigos, embora alguns até agora, como o Miguel Lobo Antunes ou o José Mariano Gago. Na faculdade: olha que bom! Aqui há rapazes e raparigas. Vamos lá criar o Grupo de Teatro da Faculdade de Letras! Aí comecei a ter interesse nos cineclubes, a participar no ABC, depois no CCUL [Cineclube Universitário de Lisboa] e sobretudo no teatro, onde começámos em 1969, creio eu, com o Anfitrião. Antes tinha feito umas coisinhas, como o Avejão, de Raul Brandão. Mas foi sobretudo o Anfitrião. 


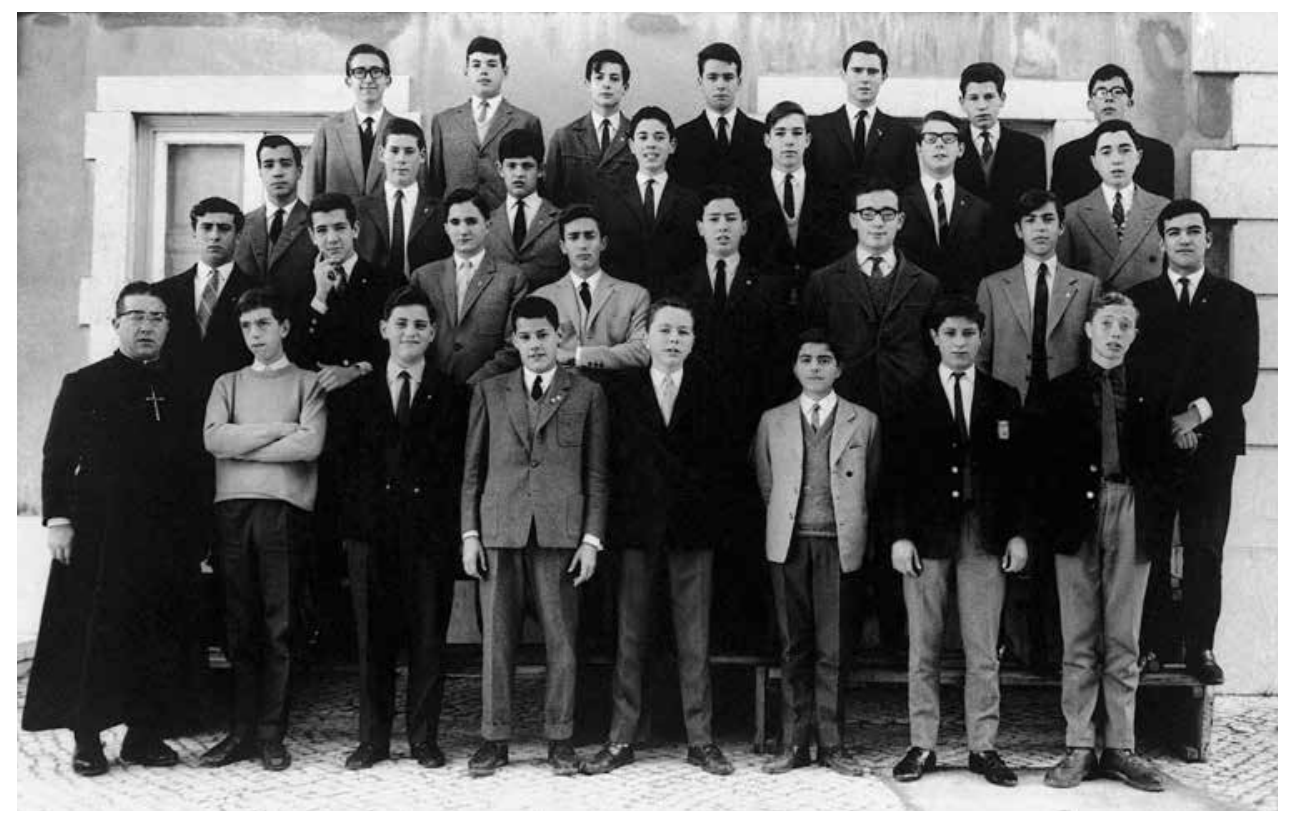

FOTOGRAFIA DE TURMA NO EXTERNATO MARISTA DE LISBOA (JORGE SILVA MELO,

2. ${ }^{a}$ FILA, $6 .{ }^{\circ}$ A PARTIR DA ESQUERDA), 1960

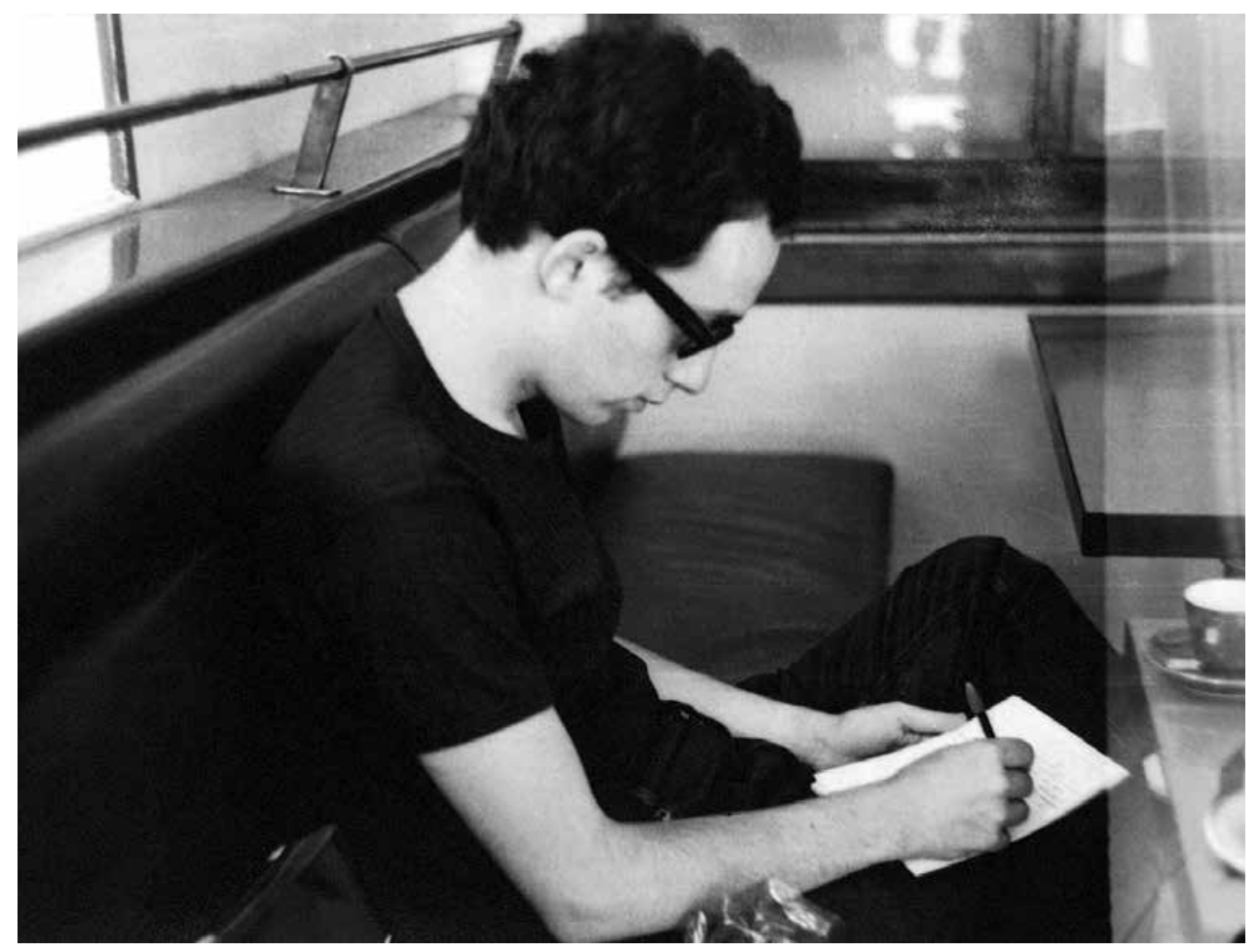

JORGE SILVA MELO, AVIGNON, 1968, [F] LUÍS FILIPE SALGADO MATOS 


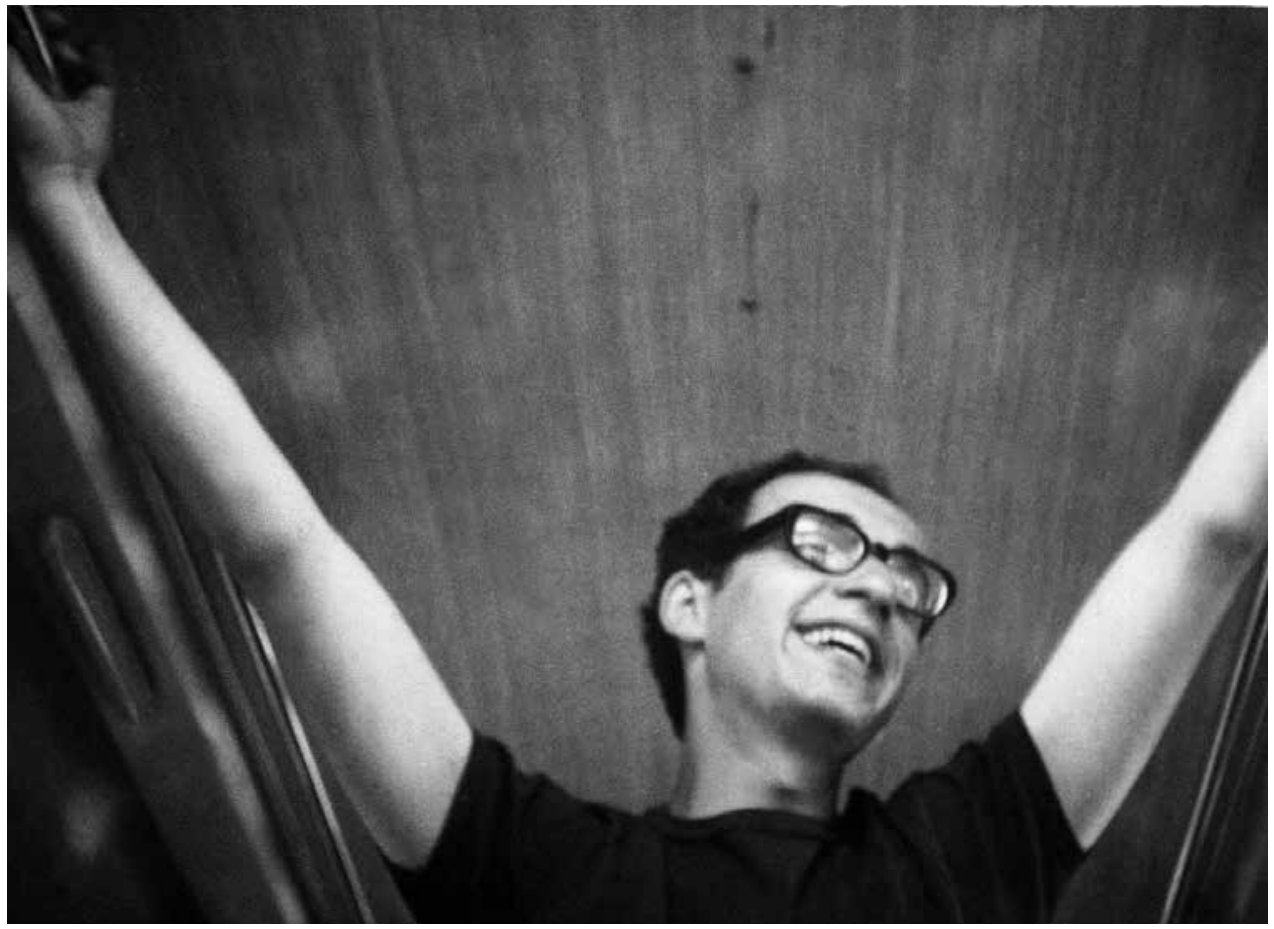

JORGE SILVA MELO, DE VIAGEM ENTRE ANTIBES E NICE, 1968, [F] DESCONHECIDO

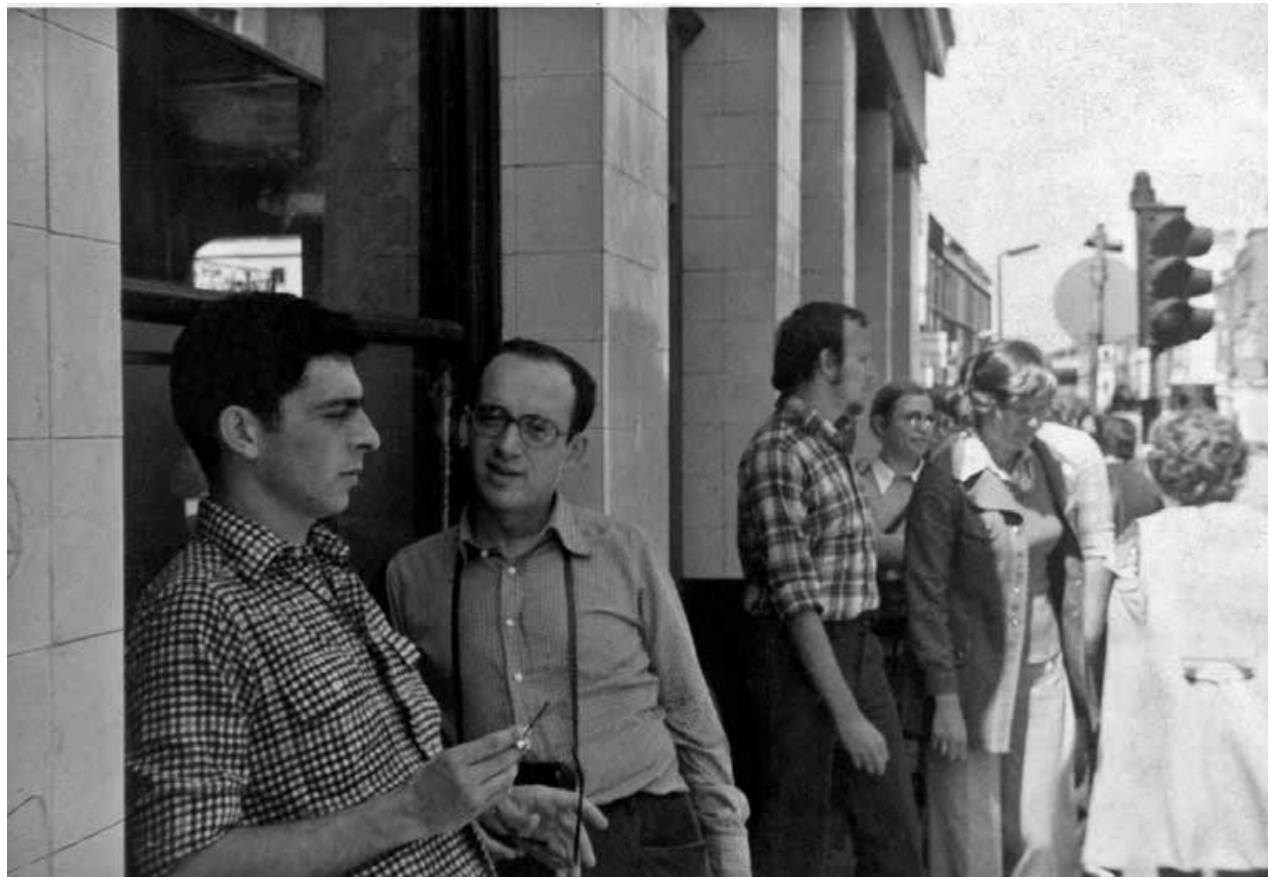

LUIS MIGUEL CINTRA E JORGE SILVA MELO, C. 1970, LONDRES, [F] DESCONHECIDO 
Eu tinha vinte anos, o Luís tinha dezanove. Tentámos continuar a seguir à faculdade com um grupo de teatro amador [Grupo de Teatro do Ateneu Cooperativo], onde criámos os Três Entremezes de Cervantes [1970], que foi feito na Sociedade Nacional de Belas-Artes, mas que já não foi tão bem acolhido, acharam que era mais do mesmo, embora eu gostasse bastante do espectáculo.

Havia teatro na Faculdade de Letras, havia professores que o faziam, mas criar um grupo de teatro em Letras... 0 que é que acontecia do ponto de vista das actividades culturais num tempo em que tudo era proibido e feito um bocadinho à margem dessa faculdade, que já retrataste como sendo pouco interessante? Que actividades é que havia? Onde é que entra Gastão Cruz e outros? É depois? É antes? Havia outras coisas?

Comecei a escrever para o Diário de Lisboa, fui criando amigos e inimigos. Imagina: havia nessa altura um prémio (dado pela Fosforo Ferrero, uns comprimidos que ajudavam a memória, muito usados em época de exames)... Os três premiados, quem foram? O José Mariano Gago, o José Pacheco Pereira e eu. [risos] Que monotonia, ainda agora são sempre os mesmos. Tínhamos dezoito anos. Digamos que a elite à volta do Diário de Lisboa Juvenil foi muito forte e manteve-se durante anos. O Luís Filipe Castro Mendes foi meu antagonista numa polémica que demorou quase um ano, quando eu tinha para aí dezoito anos e ele quinze ou dezasseis, sobre o Zorba, o Grego. Eu disse muito mal do filme e ele respondeu a dizer que o livro era muito bom, ao que se seguiu uma polémica com ele a dizer que o livro era muito bom e eu a dizer que o filme era mau e que não tinha uma coisa a ver com a outra, e que maus romances podiam dar bons filmes, etc. A certa altura, recebo uma carta: «Eu sou aquele que te insulta às terças-feiras, mas gostava muito de ser teu amigo.» Era o Luís Filipe Castro Mendes, que já era assinante dos Temps Modernes, já tinha lido O Ser e o Nada, de Sartre, em Chaves! [risos] Filho do juiz...

\section{Bem, parecia um país extraordinário.}

Mas como é que ele percebeu alguma coisa? [risos] Fui passar férias com ele e com um amigo dele. Por escrever no Diário de Lisboa Juvenil, dei nas vistas por uma certa heterodoxia. Atacava filmes muito louvados, dizia 
bem de filmes que eram malvistos, como os de Jerry Lewis, por exemplo, acabei por congregar muita gente que vinha de fora de Lisboa a quem eu acabei por apresentar Lisboa. Servi, de certo modo, de introdução à vida lisboeta... [risos]

Na FLUL, o Gastão... a Fiama [Hasse Pais Brandão] ainda era aluna, creio que o Gastão já não, mas o Gastão começa a dirigir um grupo de poesia paralelo ao grupo de teatro... O Gastão fazia umas leituras de poesia que eram muito concorridas, na Livraria 111, com a Maria Barroso e o Luis Miguel [Cintra]. Eu não tinha muito jeito para ler, portanto, fui atirado para fora. Mas eram, também, a Ana Maria Teodósio, a Helena Domingos. Um parêntese: a Livraria 111 não era só livraria, era também galeria, onde expunham artistas que eu ia descobrindo, o Álvaro Lapa, o [Joaquim] Bravo, o António Sena, a Lurdes Castro. Estas leituras de poesia que o Gastão organizava eram uma actividade paralela ao grupo de teatro da Faculdade de Letras e que acho que só começa, mas não tenho a certeza, depois d'O Avejão, de Raúl Brandão, que a Carmen Gonçalez dirigiu em 1968, com cenários do Manuel Baptista. Era aquele grupo que se juntava muito num café que já não existe, chamado Monte Branco, uma gelataria no Saldanha, onde agora é um banco ou uma coisa qualquer. Mesmo no Saldanha, quase no prédio onde viveu o Carlos de Oliveira. Havia muita gente que ia traduzir para lá, o [António] Ramos Rosa estava lá desde manhã, a Alice Gomes, que morava ao lado, a Carmen Gonzalez, que também esteve no Grupo de Teatro de Letras, traduzia Malcolm Lowry. Cada um na sua mesa a fazê-las à mão. Não era ao computador. Eram os poetas, que iam para lá de manhã, porque não tinham outro emprego, a não ser as traduções. Esses fui conhecendo, também, o Ramos Rosa, a Luiza [Neto Jorge], o Herberto Helder, que não era dos tradutores, mas aparecia lá pelas quatro da tarde. Estavam nesse café, que tinha para aí seis mesas. Não tinha mais, depois tinha uma esplanada no verão. Esse era o grupo dos escritores. Aí, também me dei muito com o Gastão e com a Fiama. Mais até com a Fiama, a meu ver. A Fiama fazia crítica teatral, numa revista [do Cineclube] do Porto, chamada Plano, uma revista de cinema e de teatro, dirigida pelo Egito Gonçalves.

\section{E vocês eram convidados para escrever porque vos conheciam ou enviavam os textos e diziam que queriam escrever sobre cinema?}

Quando comecei a escrever no Juvenil, foi porque mandei um texto para lá e o Castrim aceitou. A partir daí, comecei a receber convites. O João 


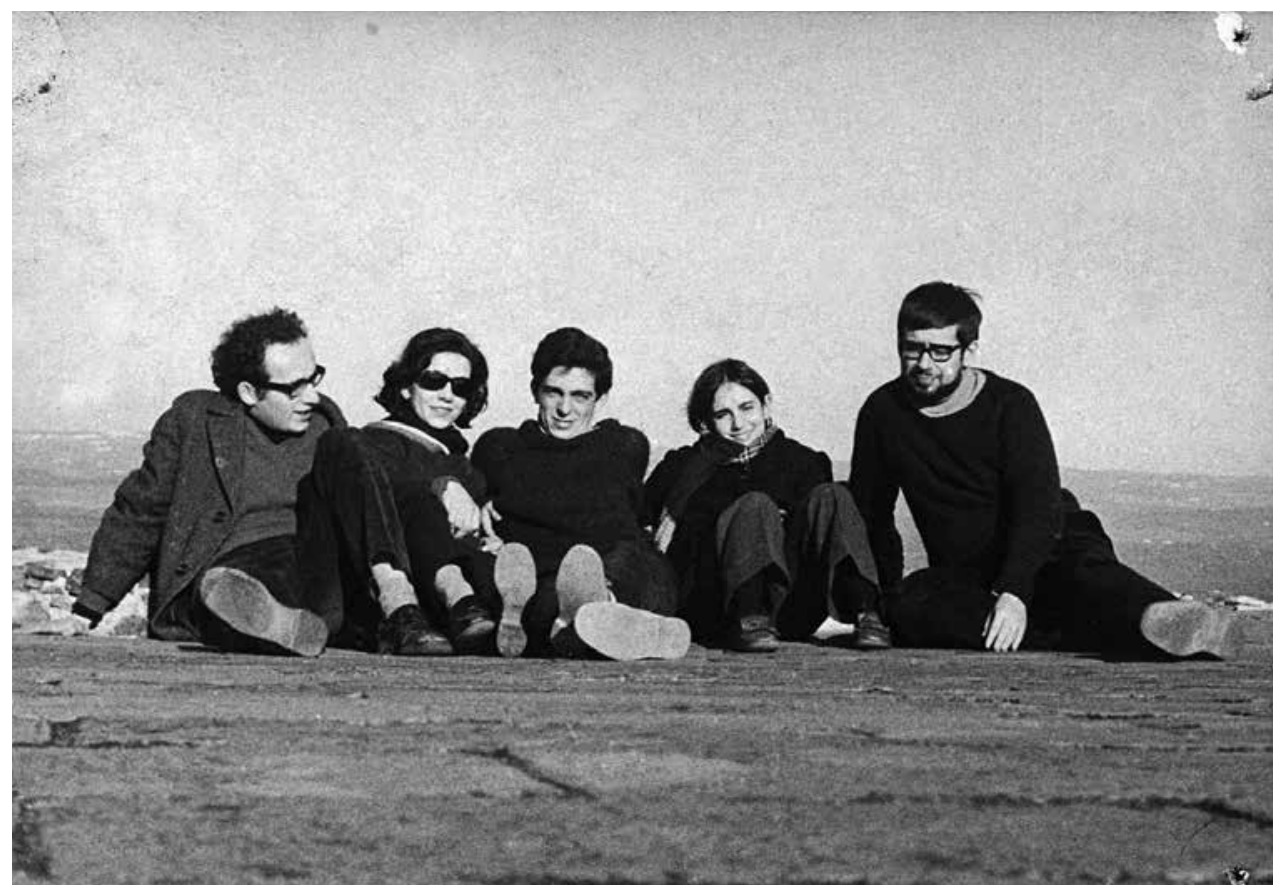

JORGE SILVA MELO, MARGARIDA SOROMENHO, LUIS MIGUEL CINTRA, EDUARDA DIONÍSIO E LUÍS SALGADO MATOS, 1970, ÉVORA-MONTE
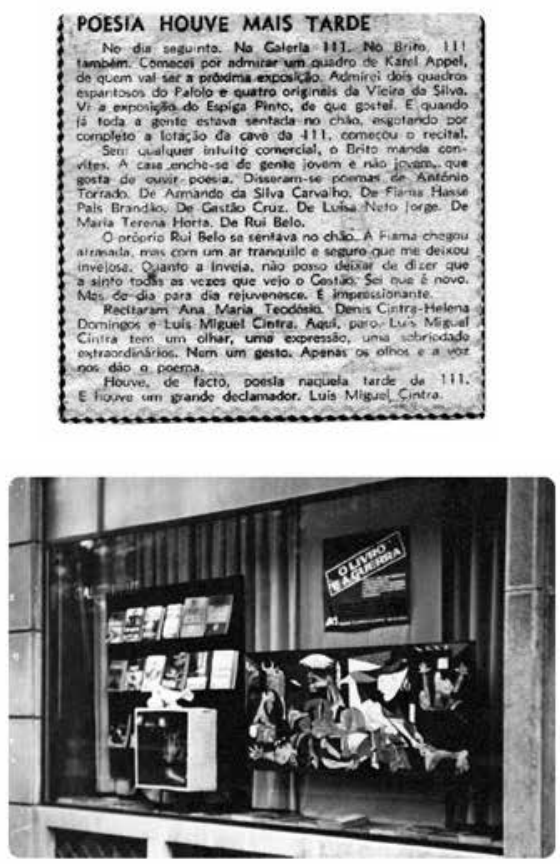

NOTÍCIA DO DIÁRIO POPULAR DE 5 DE JUNHO DE 1969 E MONTRA DA LIVRARIA 111, PELA MESMA DATA [MONTAGEM A PARTIR DE FOTOS CEDIDAS PELA LIVRARIA 111]

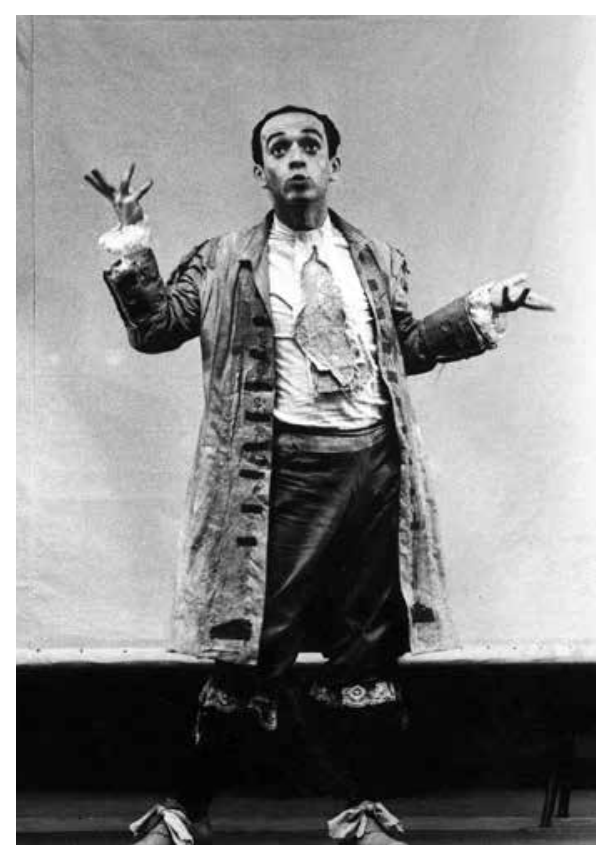

O MISANTROPO OU O ATRABILIÁRIO APAIXONADO, DE MOLIÈRE, ENC. LUIS MIGUEL CINTRA, TEATRO DA CORNUCÓPIA, 1973 (JORGE SILVA MELO), [F] PAULO CINTRA GOMES 


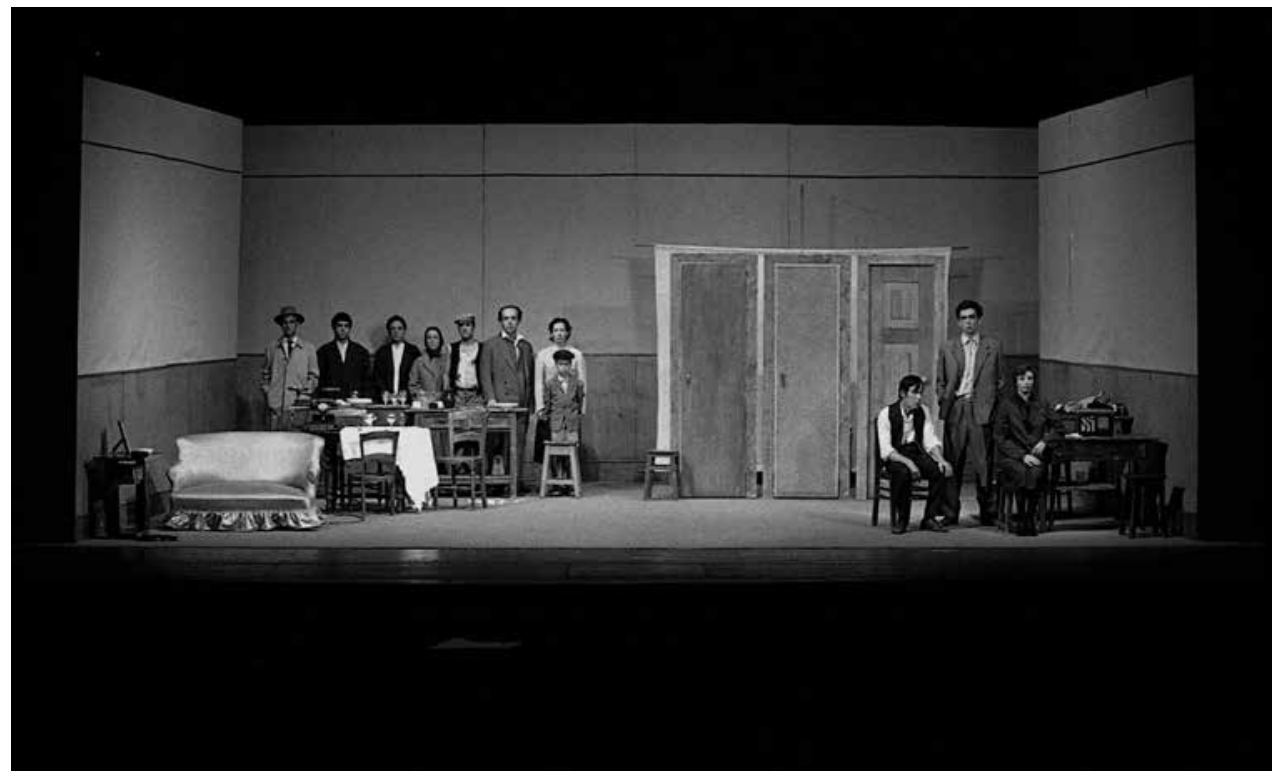

O TERROR E A MISÉRIA NO TERCEIRO REICH, DE BERTOLT BRECHT, ENC. JORGE SILVA MELO E LUIS MIGUEL CINTRA, TEATRO DA CORNUCÓPIA, 1974 (LUIS LIMA BARRETO, CARLOS FERNANDO, RAQUEL MARIA, ORLANDO COSTA, JORGE SILVA MELO, GLÓRIA DE MATOS, PEDRO PENILO, AUGUSTO FIGUEIREDO, LUIS MIGUEL CINTRA, GLICÍNIA QUARTIN), TEATRO DA TRINDADE, [F] PAULO CINTRA GOMES

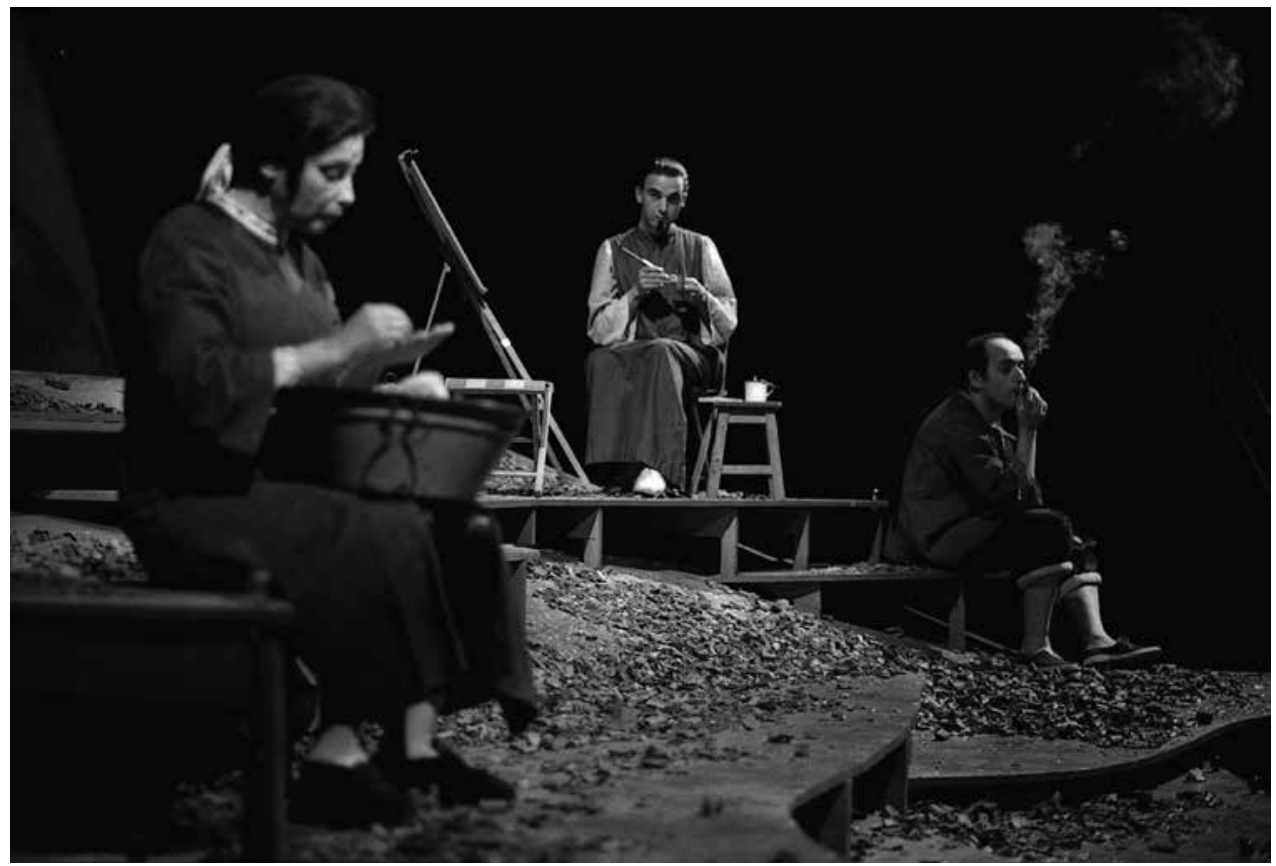

AH Q!, DE JEAN JOURDHEUIL E BERNARD CHARTREAUX, ENC. LUIS MIGUEL CINTRA, TEATRO DA CORNUCÓPIA, 1976, (GLICÍNIA QUARTIN, LUÍS LIMA BARRETO, JORGE SILVA MELO), [F] PAULO CINTRA GOMES 
Bénard convida-me para escrever n'O Tempo e o Modo sobre cinema. O António-Pedro Vasconcelos, quando dirige a segunda fase do Letras eArtes, convida-me para escrever sobre teatro. Eram convites que vinham porque já tinha criado uma certa polémica, com a minha passagem pelo Diário de Lisboa Juvenil. Aquele Juvenil, que saía às terças-feiras, era um suplemento que os adultos também consultavam para saber quem é que estava aí a aparecer. $\mathrm{E}$ que era muito lido pelos jovens de fora de Lisboa e da oposição, era a única coisa que tínhamos...

Essa formação informal fazia-se muito assim: escrevendo, estando, falando, encontrando-se, discutindo, acompanhando as publicações...

Era uma época de mudanças profundas - como provavelmente todas... Por exemplo, havia uma coisa que era muito engraçada: o Artur Ramos e o Lauro António, próximos do PC [Partido Comunista] ou dentro do PC ainda os dois na altura, sentiram que se aproximava o fim dos cineclubes (associações) e começaram a fazer, no Monumental, sessões para toda a gente, como já havia no Tivoli e no Império há uns bons anos. «Sessões clássicas» que se chamavam «Quinzenas do bom cinema». Às segundas, quartas e sextas, às seis e meia, num cinema de mil e tal lugares, íamos todos ver filmes escolhidos por esta dupla. Sem se ser sócio, podíamos ir ver filmes muito bem escolhidos. Isto acabou por ser um ataque involuntário aos cineclubes, que começam a definhar, também atacados pelo regime. Como estávamos todos ali perto no Saldanha, íamo-nos orientando, íamos trocando informações. Acabei por ser o conselheiro, por exemplo, do Ruy Belo, que me vinha perguntar quais eram os filmes que devia ver naquela quinzena. E falávamos, falávamos sem fim... Lembro-me de que no meu terceiro ano de faculdade... Deve ser o terceiro - foi o cinquentenário do Húmus, de Raul Brandão. O livro já quase não se encontrava, estava quase esgotado e não foi reeditado na altura, mas houve um suplemento literário do Diário de Lisboa que prestou atenção a esse cinquentenário. O Jacinto Prado Coelho, meu professor, que só dava literatura até Camilo, deu Raul Brandão nesse ano. Houve uma abertura inesperada na FLUL. E eu tive-o a dar Raul Brandão; e saiu-me no exame («Será Húmus um anti-romance?», foi a pergunta). E o Carlos de Oliveira havia de escrever o Finisterra, assim como o Herberto também iria escrever o Húmus, pegando em frases de Raul Brandão e fazendo um poema a partir disso. Eram acontecimentos que explodiam naquele pequeno grupo 
de pessoas inesquecíveis. Desde o Carlos de Oliveira, que tinha mais trinta anos do que eu, ou o Gastão, que tinha mais dez, ou o Herberto, que tinha mais vinte. Íamos congregando informações. Assim como os filmes. O Herberto passava a vida a falar de um filme do Joseph Losey, Dois Vultos na Paisagem [1970], que era o seu filme favorito. Lembro-me perfeitamente de ter ido ao Monumental ver esse filme e de ele lá estar no segundo balcão. Assim como me lembro de ter visto pela primeira vez o Esplendor na Relva nessa altura. O filme é de 1961, mas eu vi-o em 1967, para aí... a sala inteira riu à gargalhada. Inclusive o Ruy Belo, que estava ao meu lado, e depois veio a escrever aquele poema maravilhoso sobre a Deanie. Foi uma risota. Fazia-se troça da Natalie Wood, que nessa altura era considerada a pior actriz do mundo e todos os anos recebia o Turkey, o Óscar para a pior interpretação. E agora olhamos e é maravilhosa. Já o era, nós é que não víamos [risos]. «Como é possível um filme tão piroso?» Passado para aí três meses fomos ver, cada um por si, e chorámos às escondidas. Afinal era uma obra-prima. Não se podia era ver com mil e tal pessoas a rir [risos].

Mas o grande sonho era Paris. Eu tinha o mapa de Paris no quarto, tudo o que fosse Paris, as idas e os regressos de Paris, queríamos saber tudo, que filmes estavam em exibição, que peças de teatro... que livros... era a sede absoluta de informação. Os livros, os filmes que viam e que nós não víamos. O que é que já tinha estreado. Muitas vezes, sentíamos que os jornais ou as revistas - que eram muito importantes - não tinham chegado à tabacaria do Monte Carlo, a censura tinha-os apreendido. Alguma coisa se passara... E íamos lê-las na Alliance Française, que as recebia oficialmente. «Ah! O quê? O L'Express não chegou esta quinta-feira? Não. Nem o Nouvel Observateur? Amanhã passo pela Alliance para saber o que é que eles proibiram.» $\mathrm{E}$ ia um, que depois contava aos outros, não ia toda a gente ler o L'Express.

\section{$E$, agora que falaste da censura, como era viver politicamente esse tempo, das agitações estudantis? Disseste em algum sítio que até tinhas sido preso antes do 25 de Abril.}

Acho que foi o meu espectáculo com maior êxito, para dizer a verdade. Ainda no outro dia, houve um senhor da minha idade que me disse: «Ai, eu assisti à tua prisão e fiquei impressionadíssimo.» Não sei quantos anos depois... Partiram-me a cabeça, fiquei cheio de sangue... Nunca tinha pensado vir a ser um herói gore. Fui protagonista de um filme de 
terror. O João Soares também assistiu, do outro lado da rua. Não se esqueceram. Esse é que foi um bom espectáculo.

\section{Mas isso aconteceu em que contexto?}

Foi no dia da manifestação internacional contra a guerra do Vietname, que coincidia com o regresso do Américo Tomás de uma colónia qualquer. Cá ganhava um triplo significado... E eu estava com a Maria Andresen, filha da Sophia, íamos lado a lado... Os pides queriam prendê-la a ela, não era a mim. Andaram atrás de nós, consegui defendê-la, mas fiquei um bocadinho para trás e fui apanhado. O que é muito engraçado, visto agora, é que, vivendo sob uma ditadura, tudo o que não era uma ditadura, para nós era de esquerda. Só muito mais tarde é que descobri que o De Gaulle era de direita [risos]. Porque tudo o que não fosse Portugal ou Espanha era liberdade, era tudo maravilhoso. Nunca pensei que houvesse fascistas em França. Não me passava pela cabeça. Ou que mesmo alguns dos autores de que eu muito gostava tivessem tido tendências fascistas, como o [Georges] Bernanos, que muito admirava e admiro. Espanha, nesses anos 60 , era diferente, tinha uma censura mais liberal do que a nossa, saíam muitos livros, filmes e peças de teatro que cá eram proibidos, como a Mãe Coragem; o Brecht era representado em Espanha e cá não.

\section{E Londres?}

Vou para Londres em 1970, ou seja, tinha vinte anos em 1968, quando fui preso. Quando pedi a bolsa à Gulbenkian, queria ir para Paris, mas nessa altura não valia a pena ir estudar o que quer que fosse para França. Ir estudar para lá era não ir a aula nenhuma, e a Gulbenkian não me dava bolsa para ir para lá fumar charros [risos] durante dois anos. Fui para Londres. A escola era muito má, contrariamente ao que se dizia. Tinha sido uma muito boa escola técnica, The London School of Film Technique. Naquele ano, por acaso, e suponho que por causa do Maio de $1968 \mathrm{em}$ França, o British Film Institute [BFI] estava a criar uma escola própria e tinha retirado da nossa escola todos os bons professores. Mas essa escola do BFI ainda não estava a funcionar; estavam a preparar o currículo da nova escola. A nossa ficou desfalcada. Quem frequentava a nossa escola, que era privada, eram filhos de milionários, muitos eram americanos. Aquilo era caríssimo. Eu não pagava, era bolseiro da Gulbenkian, que financiava a própria escola. Mas o meu colega, de quem fiquei amigo desde 
o primeiro dia até ao último e com quem ainda, de vez em quando, troco e-mails... Imaginem quem é. Chama-se Nicholas... Pritzker. É o homem que dá os prémios de arquitectura, filho do milionário de Chicago, judeu. Abandonou o cinema, mas dá os prémios de arquitectura. Isso era a frequência daquela escola. E eram os meus amigos, o Nicky Pritzker, o Eric Young, que se casou com uma sobrinha e herdeira do Graham Greene, gente com muito, mas mesmo muito dinheiro, com casas em Chelsea ou Hampstead Heath... O que é que me interessou em Londres? O teatro. A minha cultura cinéfila era francesa e não inglesa. Em Londres, só havia os êxitos americanos, mais nada. Não havia cineclubes, nem cinemas de arte e ensaio, eu queria era ir para Paris tomar cafés (em Londres não havia) e ver filmes autênticos... Mas o teatro interessou-me muito. Vi o trabalho de grandes directores: John Barton, Dexter, Bergman, Wajda e sobretudo William Gaskill (que soube que morreu agora e a quem, há um ano ou dois, tive a oportunidade de agradecer todo o prazer que me deu...). Entre 1969 e 1971, vi todo o teatro possível e todas as alterações de teatro que existiram naquela cidade. Ia para as aulas de cinema, mas depois, ao fim da tarde, ia para o teatro. E a Ingrid Bergman estava a representar num teatro cuja porta dos artistas dava para a minha escola... Estava em Londres, coisa absolutamente extraordinária.

\section{Quando voltas, voltas para o cinema?}

Quando volto, volto para o cinema. Volto para trabalhar imediatamente, como assistente de realização do António-Pedro Vasconcelos. Já tinha sido assistente de realização do Paulo Rocha e do João César [Monteiro]. Na semana seguinte ao meu regresso, já era assistente de realização do António-Pedro, no primeiro filme dele, Perdido por Cem [1972]. Foi tão rápido... Umas semanas depois de ter acabado o curso, um meu amigo de escola, que me veio visitar, imaginem, chegou ao aeroporto e lá estávamos a filmar. Ficou impressionadíssimo: «Já tens trabalho!? Já estás a filmar uma cena de morte no aeroporto?!» E eu, todo megafone a dar ordens de primeiro-assistente.

\section{Isso corresponde ao momento do cinema apoiado pela Gulbenkian?}

Sim, era o fim do programa de apoio ao cinema da Gulbenkian, em que fui assistente do António-Pedro, no Perdido por Cem, e logo a seguir, do Alberto Seixas Santos, no Brandos Costumes [1975], ou seja, fiz os dois 


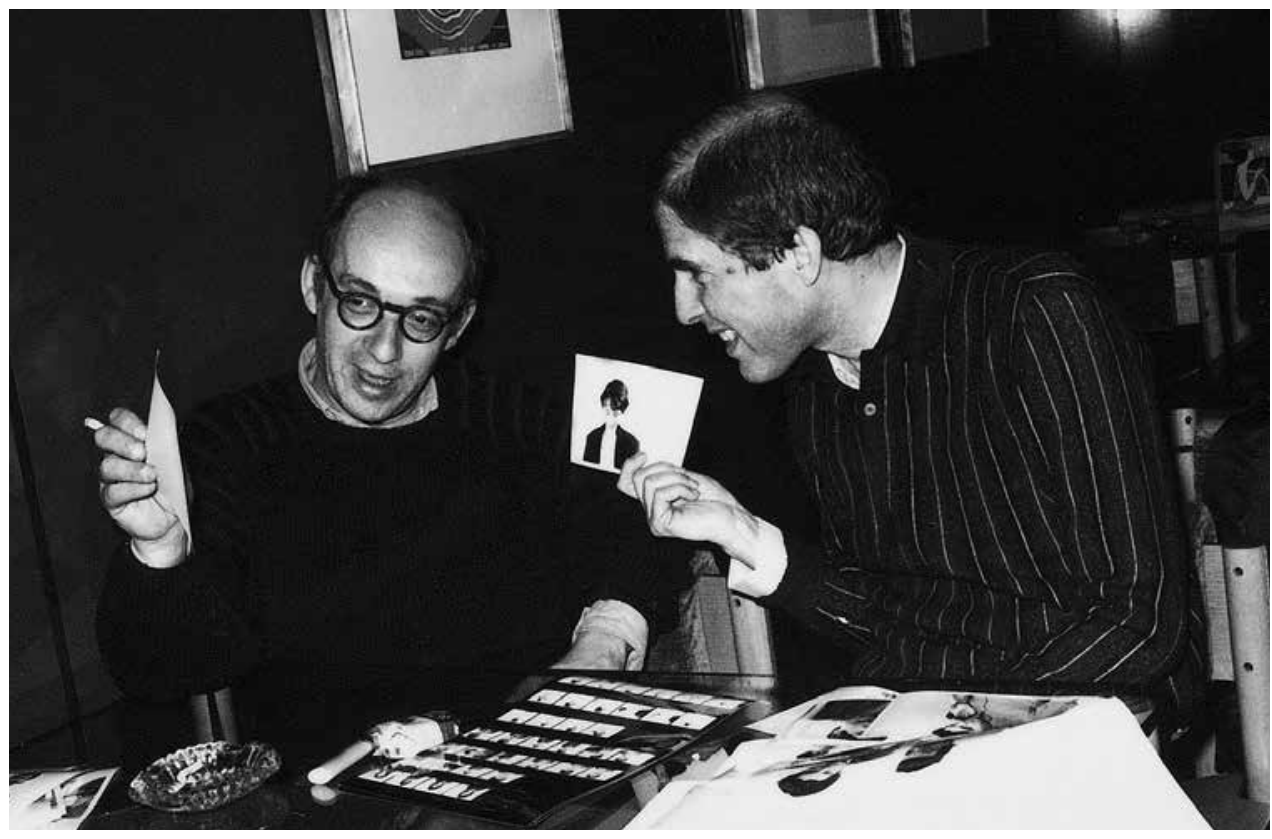

JORGE SILVA MELO E PAULO ROCHA, C. 1980

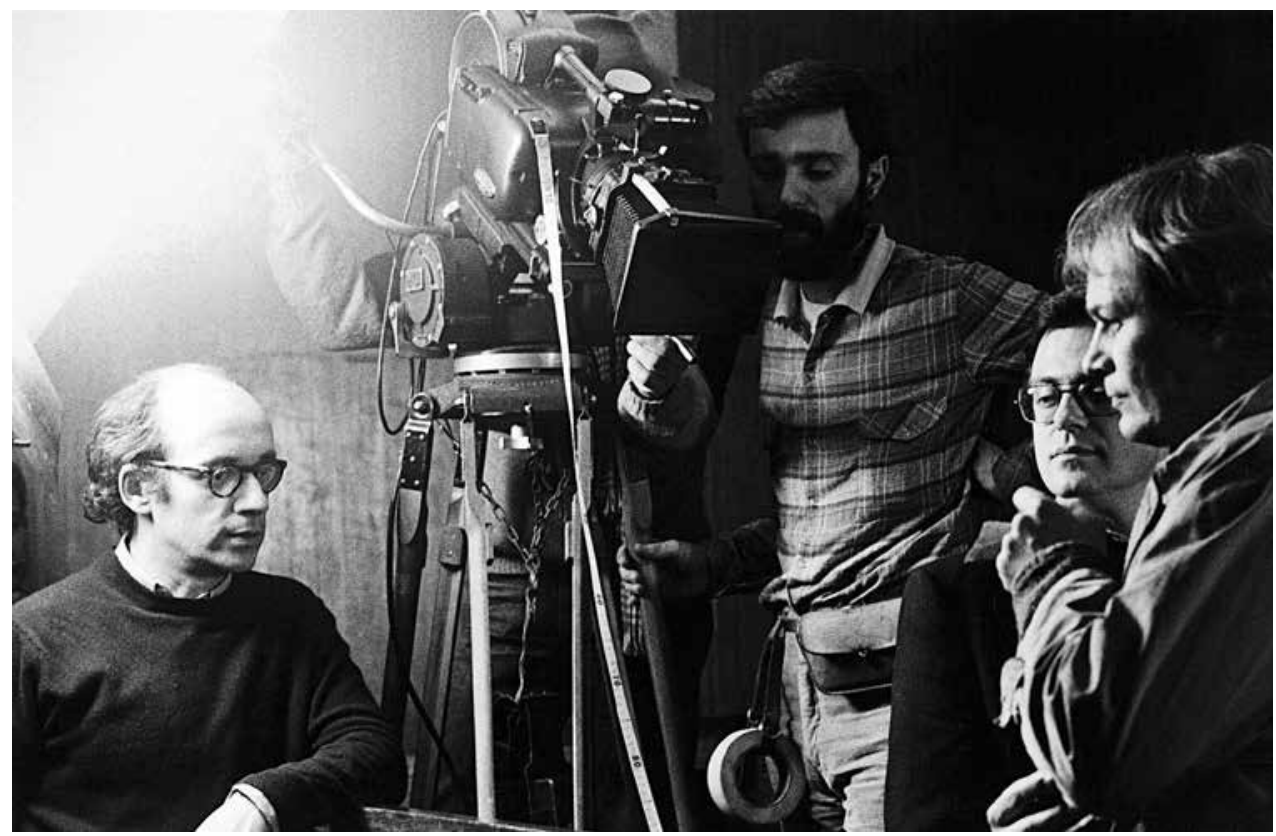

JORGE SILVA MELO, ACÁCIO DE ALMEIDA, JOSÉ ANTÓNIO LOUREIRO, MICHAEL KÖNIG, NA RODAGEM DE NINGUÉM DUAS VEZES, 1983, [F] JOÃO PINTO NOGUEIRA 
últimos filmes do programa Gulbenkian e depois aquilo acabou. Fiquei sem trabalho. Mas os anos de 1971 e 1972 foram como assistente de realização no cinema. Nós, no cinema, sentíamos que estava a acabar aquela pequena renovação que a Gulbenkian tinha proporcionado, mas o que estava a acontecer no teatro estava muito vivo. Primeiro Os Bonecreiros, onde houve uma cisão grande que deu a Comuna. Uma série de pessoas que eu admirava, como a Glicínia Quartin, o Mário Jacques, estavam a sair das companhias normais para criar as suas estruturas e isso deu uma grande esperança. Aliás, o elenco dos Brandos Costumes é um elenco que fui eu a escolher, à excepção da Isabel de Castro, que já era amiga do Alberto. Porque o Alberto Seixas Santos não conhecia os actores. Quem é que eu recomendei? A Dalila Rocha, actriz que vinha do TEP, ou seja, das tais marginalidades de oposição anterior. O Luís Santos, que era um actor republicano, que vinha da grande escola anarquista (aluno do Araújo Pereira, amigo da Manuela Porto) e que trabalhou aqui mesmo, dentro da Politécnica. Fez os Limões da Sicília [1950], do Pirandello, com o grupo da Manuela Porto [Corpo Cénico do Grupo Dramático Lisbonense] e depois fez algumas coisas, mas sempre olhado de soslaio, porque era da oposição. Tinha trabalhado um bocadinho com a Luzia [Maria Martins], mas tinham sido os à margem do teatro oficial. $\mathrm{E}$ o elenco, achei que tinha resultado muito bem. Também por serem pessoas que estavam disponíveis para aquilo. Nem fazíamos plano de trabalho. Os actores todos iam para as filmagens, entrassem nesse dia ou não. Depois vinham todos almoçar, ficavam ali a conversar.

\section{A ideia é essa: tu vens para fazer cinema, apesar de tudo, e de repente...}

O cinema em Lisboa estava a morrer nessa altura e o que estava a nascer era algum teatro. Ainda trabalhei n'Os Bonecreiros um bocadinho, num espectáculo, mais ou menos como dramaturgista, juntei os textos de teatro de cordel. Trabalhei com umas editoras, ganhava a vida como tradutor. Com a Estampa e a Seara Nova, lancei uma colecção de teatro, com o Luis Miguel e com o José Alberto Osório Mateus, onde publicávamos os textos que eu gostaria de vir a fazer numa companhia que eu tivesse. Essa colecção é anterior à formação da Cornucópia. Com a Cornucópia, justamente, essa colecção morre; não havia tempo para estar a organizar a colecção e fazer os espectáculos, mas foi uma espécie de repertório para uma companhia. 
E portanto a Cornucópia nasce precisamente no meio dessa instabilidade relativamente ao cinema...

Sim, o cinema estava completamente morto quando a Cornucópia nasceu, já estavam prontos todos os filmes dessa segunda geração, não havia mais trabalho. Ainda trabalhei numa revista que fundei com os meus amigos, a Eduarda Dionísio, o Luís Salgado de Matos, chamada Crítica, durou um ano intenso e gosto muito do que conseguimos fazer, polémicos.

\section{E também nasceu de um certo desafio das pessoas que conheceste e que eram os teus colegas e do Luis Miguel Cintra, não é?}

Exacto, e também a possibilidade de alguns actores profissionais muito reconhecidos, como a Glicínia, a Dalila, quererem vir trabalhar com miúdos. Agora seria impensável uma companhia com os dois chefes, o Luis Miguel e eu, com vinte e três anos, convidar a Alexandra Lencastre para vir trabalhar connosco... Era impensável. Não só os miúdos não se lembravam, como ela não aceitava. Mas a Glicínia aceitou, toda contente, e a Dalila e o Filipe La Féria, que estava muito na moda como jovem galã. Vieram todos trabalhar connosco porque sentia-se que eram coisas novas. A Lia Gama estava em Angola e disse numa entrevista que o nascimento da companhia era o grande acontecimento que havia em Portugal. Portanto, estava no ar do tempo.

Entretanto, deu-se o 25 de Abril, e a Cornucópia também se envolveu naquilo que acontecia na altura. Foram com o Terror e Miséria no Terceiro Reich para as campanhas de dinamização. Como foi essa experiência?

Foi um momento muito crítico em que eu estava em grande oposição à ideologia do teatro que era praticada. Que era muito «temos de fazer espectáculos exortativos, em que se diga às pessoas o que devem fazer para serem bem-comportadas!», e eu achava que o importante seria meditar sobre as contradições da pequena burguesia. A partir do Terror e Miséria no Terceiro Reich, de Bertolt Brecht, que fizemos em 1974 e que já é sobre isso, houve uma série de peças - Os Pequenos Burgueses, do Gorki, Os Tambores na Noite [Brecht], o Casimiro e Carolina [Horváth] - na Cornucópia sobre a pequena burguesia, que são os porteiros do 


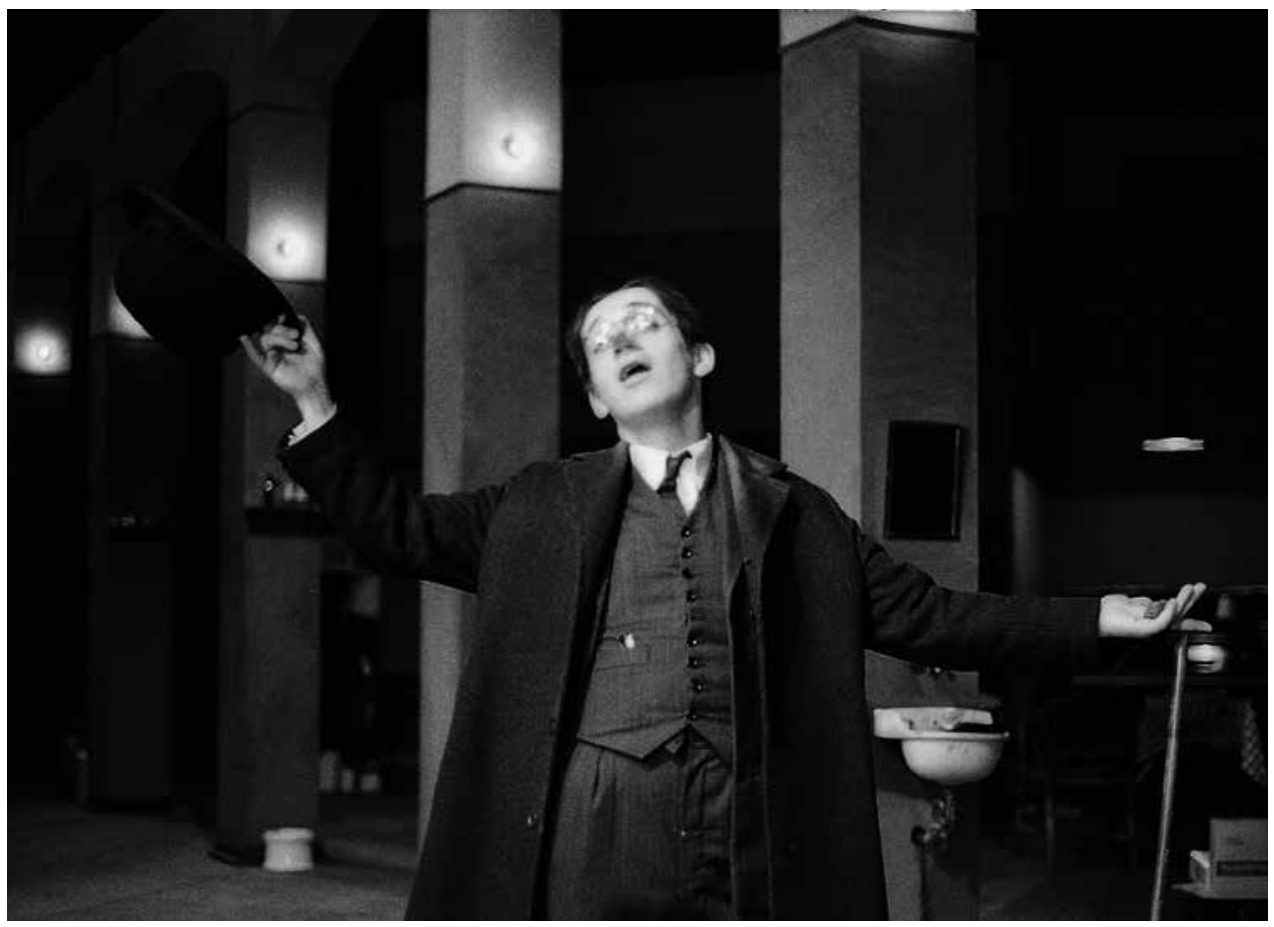

E NÃO SE PODE EXTERMINÁ-LO?, DE KARL VALENTIN, ENC. JORGE SILVA MELO, TEATRO DA CORNUCÓPIA, 1979 (JORGE SILVA MELO), [F] CRISTINA REIS

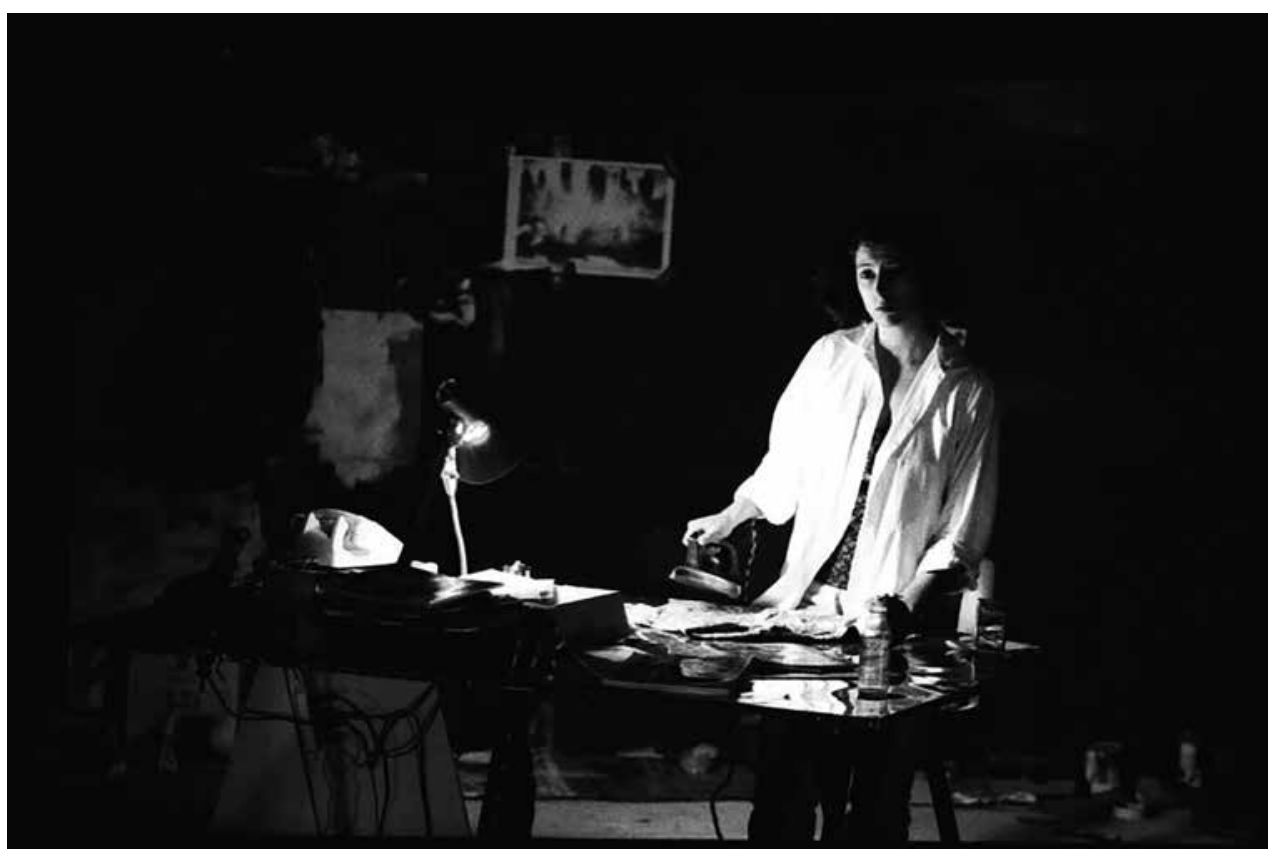

SEIS RAPAZES, TRÊS RAPARIGAS, DE JORGE SILVA MELO, TEXTO E ENC. JORGE SILVA MELO, CENDREV, 1993 (RITA TOMÉ), [F] ÁLVARO CORTE REAL 


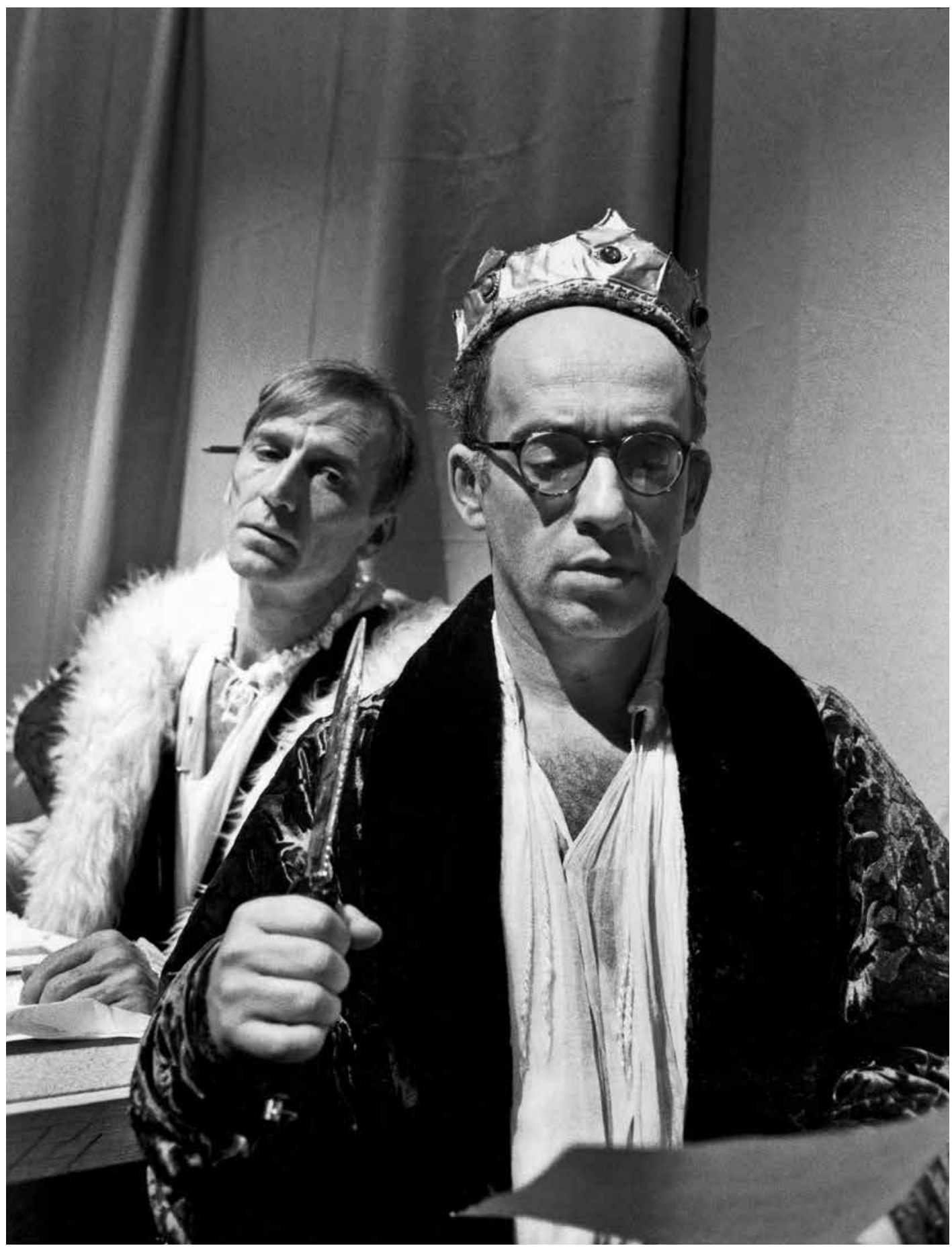

LES SONNETS DE SHAKESPEARE, DE WILLIAM SHAKESPEARE, ENC. JEAN JOURDHEUIL E JEAN-FRANÇOIS PEYRET, THÉÂTRE DE LA BASTILLE, 1990 (ANDRÉ WILMS, JORGE SILVA MELO), [F] BRIGITTE ENGUERAND 
poder. A que se juntavam algumas peças contemporâneas, Kroetz, Deutsh, daquela corrente a que se chamou teatro do quotidiano. Isso foi o centro da minha actividade na Cornucópia: encontrar repertório sobre a pequena burguesia, tudo à imagem, é evidente, do Théâtre de l'Ésperance, dirigido por Jean-Pierre Vincent e Jean Jourdheuil, e, através deles, do Schaubühne de Peter Stein. Quando saio da Cornucópia [1979], vou como bolseiro para Berlim ser assistente de Peter Stein na Oresteia, um espectáculo genial. Já não era nada sobre a pequena burguesia, mas sim sobre a derrota das revoluções. A Oresteia, a transformação das Erínias em Euménides era, no espectáculo do Peter, a morte do Exército Vermelho, o grupo dos Baader-Meinhof, a morte mesmo. A prisão dos Baader-Meinhof tinha sido uns anos antes. Era o fim de todo o ímpeto revolucionário. A domesticação, a entrada na democracia ditada pelos deuses. Aí já não estávamos nada a pensar nas fracturas da pequena burguesia, mas no fim do momento revolucionário. Isto já em 1980. Estou lá em Berlim em 1979-1980, com a Oresteia, e a seguir com Woyzeck, encenado por Michael König. Fui estagiário num Woyzeck, peça que eu já tinha traduzido e dirigido cá. Era muito engraçado ver os actores à procura do texto, que eu sabia de cor, sendo eu o estagiário estrangeiro. Tinha sido um espectáculo que me tinha dado muito gosto fazer. Foi uma experiência muito engraçada, estar todos os dias a ver um espectáculo que eu conhecia de cor feito por outras pessoas. Não era só ir ver o espectáculo. Era estar lá dois meses a assistir aos ensaios, a ver os problemas deles, «ah!, que engraçado, este problema não tive», «olha este, não me lembrava disto». Depois fui para Milão ser assistente de Giorgio Strehler, o pai de toda esta gente e tive sorte. Primeiro fui assistente num espectáculo que não era muito bom: A Boa Alma de Sé-Chuão, do Brecht, muito decorativo e muito à moda milanesa. Mas depois fui assistente na mais bonita encenação de ópera que alguma vez existiu, As Bodas de Fígaro, do Mozart, encenado pelo Strehler, no La Scala de Milão. Era impressionante a capacidade de energia e a rapidez da decisão. Na ópera, é como no cinema, as decisões têm de ser tomadas num instante. Ao filmar também. «Ai é? Está chuva? Temos de filmar o dia com sol, vamos filmar lá para dentro.» Ou filmamos ao contrário. Há o instante sublime da decisão. No teatro não, porque há sempre três meses de ensaio ou dois ou um, podemos sempre adiar para o dia seguinte. Mas o Strehler, nas óperas, tinha três semanas de ensaios. Para uma ópera! E com tempos mais que cortados com os cantores. Em três semanas, os cantores só fazem três horas de prova de guarda-roupa, a orquestra só 
ensaia quarenta minutos de seguida e depois é continuada pelo repetidor, os cantores cantam cinquenta minutos. As decisões sobre guarda-roupa e sobre encenação têm de ser tomadas ali. Até provas de guarda-roupa eram feitas durante o ensaio, com a orquestra a tocar, os músicos a cantar, os agentes a negociar cá na plateia, o Strehler aos gritos a dizer: «Questo teatro di merda!», e era o La Scala de Milão. Eu adorava isso, mas era... A energia, a visão, a capacidade de decidir. Isto é assim. Este avental é assim e acabou-se e já não há mais dúvidas... É atirar a farpa no momento absolutamente certo. Aliás, todos eles, o Stein, o Chéreau, o Klaus Grüber, vêm do Strehler e dessa fulgurante capacidade de decisão que ele tinha. E tinha de ter, porque em três semanas como é que se faz As Bodas de Fígaro com vedetas, que, ainda por cima, queriam disputar o lugar no palco? Se estão à boca de cena, se estão lá atrás... E os agentes todos a negociar isso.

Um aspecto que ficou um pouco para trás, e com ele fechamos o tema Cornucópia, tem que ver com a colecção de peças e com o que estavas a dizer sobre o Woyzeck. $O$ que é que gostarias de ter feito de diferente durante o tempo da Cornucópia? Era um trabalho conjunto, um trabalho com as outras pessoas onde havia uma determinada dinâmica, mas houve coisas que vieram contigo? Que gostavas de ter feito ali e não fizeste e ficaram sempre no teu bolso para voltares a fazer?

Sim, há várias peças que eu gostaria imenso de ter feito e que nunca virei a fazer, mas que eram peças que sonhei desde miúdo, como $A$ Vida É Sonho [de Calderón de la Barca], de certeza, Um Homem É Um Homem do Brecht e As Bodas de Fígaro, que cheguei a traduzir para o Grupo de Teatro de Letras. Coisas que o Luis Miguel acabou por fazer e que eu não farei, perdi o comboio. Tive cuidado, ao fundar os $\mathrm{AU}$, de não entrar em competição com o programa da Cornucópia. Mas eu, dentro da Cornucópia, não fui um adepto dos clássicos, não fiz nenhum Shakespeare nem nenhum Corneille, que adoro. Não fiz nada dessas coisas. Fiz um Marivaux antes do 25 de Abril, mas o que fiz foi Gorki, Horváth, o jovem Brecht, Valentin e muitos contemporâneos, nessa altura, como o Kroetz. E convidámos escritores a escrever, o Almeida Faria, a Maria Velho da Costa, projectos que ficaram por fazer. Ah, mas fiz Büchner, claro. Com os AU quis fazer contemporâneos, inventar contemporâneos (o Vieira Mendes, eu...) e as origens do teatro 
contemporâneo. Pirandello, Brecht jovem, Büchner, Pinter, os que marcam toda a escrita deste século, os antepassados directos. Acabei o jovem Brecht, fiz o Baal e a Selva das Aidades. São as coisas que trouxe. E uma coisa que a mim me interessa, e que talvez tenha que ver com cinema e com a educação cinematográfica, que é um grande respeito pelo realismo. Não tenho imaginação e não quero ter. Gosto de móveis, de ver pessoas sentarem-se em móveis e não em cubos. Se têm mesa, quero uma mesa e não um candeeiro. Isso são coisas que, se calhar, por a minha educação vir do cinema, me interessam, assim como a escrita contemporânea. Trabalhei alguns anos como argumentista de cinema, gosto de escrever para outros fazerem. Também tive o prazer de escrever peças para serem dirigidas por mim ou não, mas o prazer de estar a escrever é uma coisa que não quero perder. Gosto disso. Interessou-me menos, nos AU, também por vários acidentes pessoais, ir fazer os clássicos. Só mais recentemente é que tenho feito o grande repertório, mas aquele repertório que desde 1971 me interessa fazer, ou seja, as origens do teatro realista. A Estalajadeira, do Goldoni, é uma coisa que sempre me interessou e que traduzi para a tal colecção da Estampa/Seara Nova anterior à Cornucópia e que me interessa, exactamente por ser a origem do realismo. Gosto de ver uma pessoa pôr a mesa [risos].

\section{E, antes do regresso definitivo a Portugal, há uma ligação de amizade e um trabalho com Jean Jourdheuil. O que foi ser actor em França?}

Eu nunca tinha sido propriamente actor, porque só tinha entrado em espectáculos também dirigidos por mim, o que é diferente. Se não me apetecia ensaiar, não ensaiava. Ficava na mesa do encenador e punha outro a dizer as palavras, ou seja, nunca estive sujeito ao olhar do outro, o essencial da profissão do actor. Eu era patrão, encenador, actor, também podia ser frente de sala, como fui, mas nunca estive sujeito. Fiz alguns papéis. Bem ou mal, não interessa. No cinema, também não gostei. Não gostei nada de ser olhado. Só gostei num filme, em que também era sujeito, A Ilha dos Amores, do Paulo Rocha, filme que vi crescer e que era tão meu, que eu tinha de lá estar como actor. Só gostei de estar nos filmes quando também era autor. A certa altura, em 1984, creio eu, o Jean, com quem mantive uma amizade muito grande desde que ele trabalhou cá num espectáculo chamado $A h Q$ em 1975, convida-me para ir fazer uma peça. Foi o nosso modelo na Cornucópia. Ficámos muito amigos e convidou-me para ir fazer uma peça em que eu faria de Espinosa. 


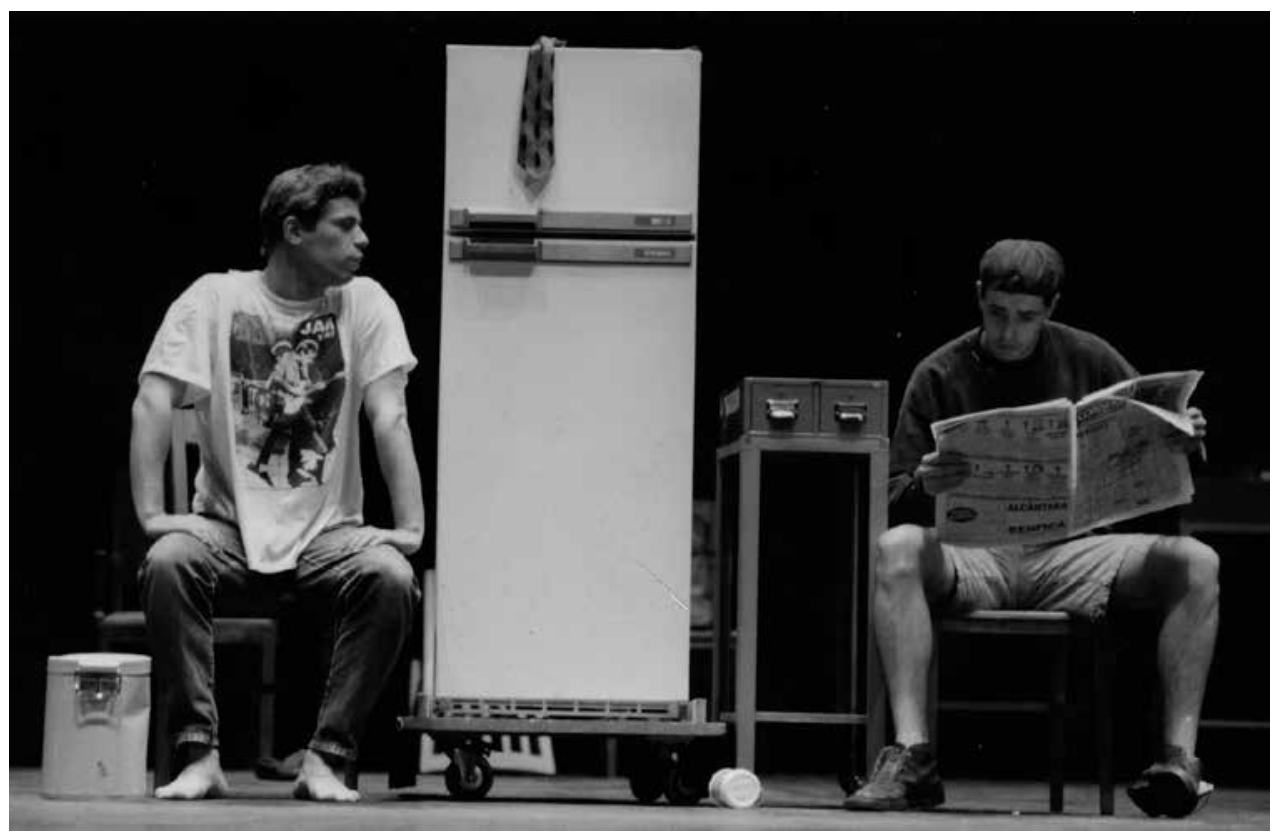

ANTÓNIO, UM RAPAZ DE LISBOA, DE JORGE SILVA MELO, TEXTO E ENC. JORGE SILVA MELO, ACARTE, 1995 (MANUEL WIBORG, PAULO CLARO), [F] JOSÉ MANUEL

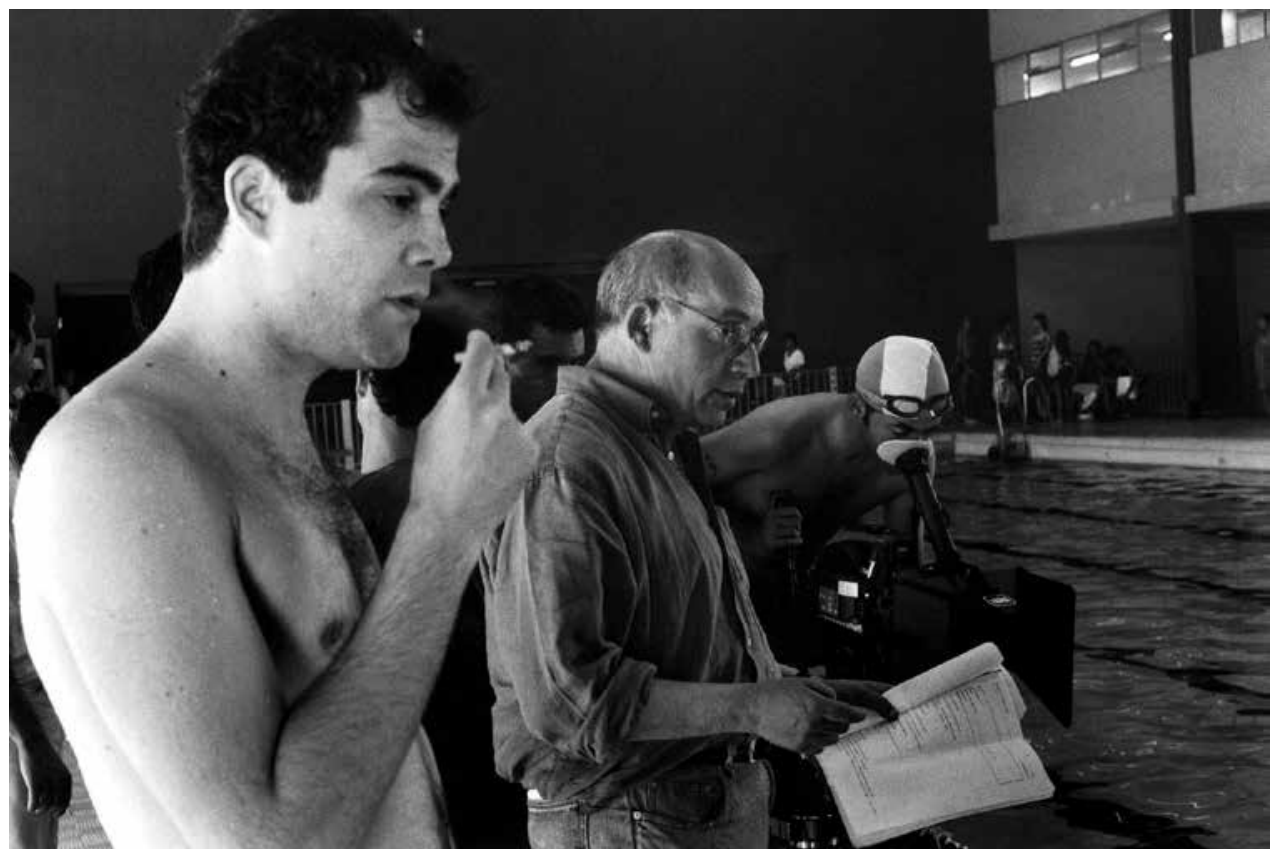

MARCO DELGADO, JORGE SILVA MELO E RUI POÇAS NA RODAGEM DE ANTÓNIO, UM RAPAZ DE LISBOA, 1999,

[F] JOÃO ABEL ABOIM 


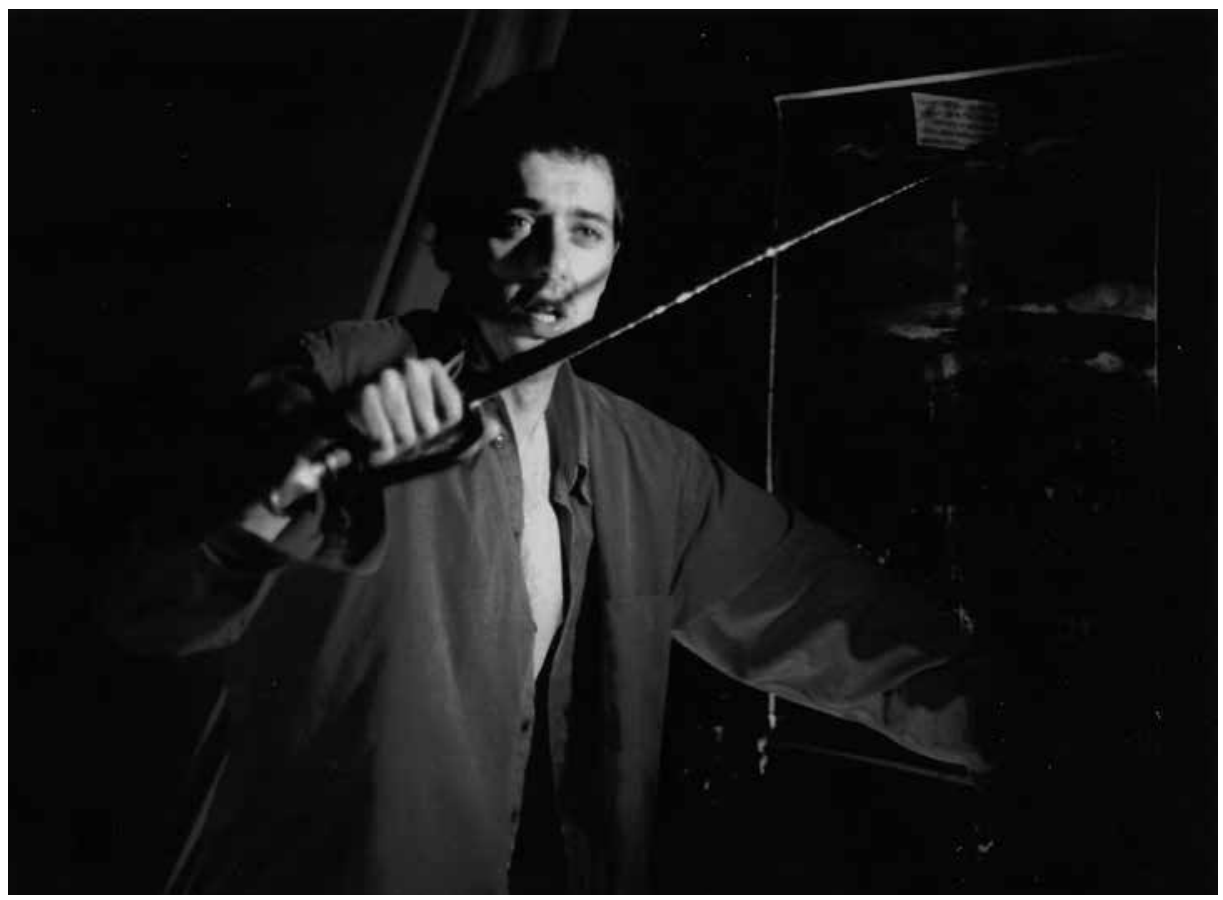

NUM PAÍS ONDE NÃO QUEREM DEFENDER OS MEUS DIREITOS, EU NÃO QUERO VIVER, DE JORGE SILVA MELO (A PARTIR DE MICHAEL KOHLHAAS, O REBELDE, DE HEINRICH VON KLEIST), ENC. JORGE SILVA MELO E PAULO CLARO, ARTISTAS UNIDOS, 1997 (PAULO CLARO), [F] SUSANA PAIVA

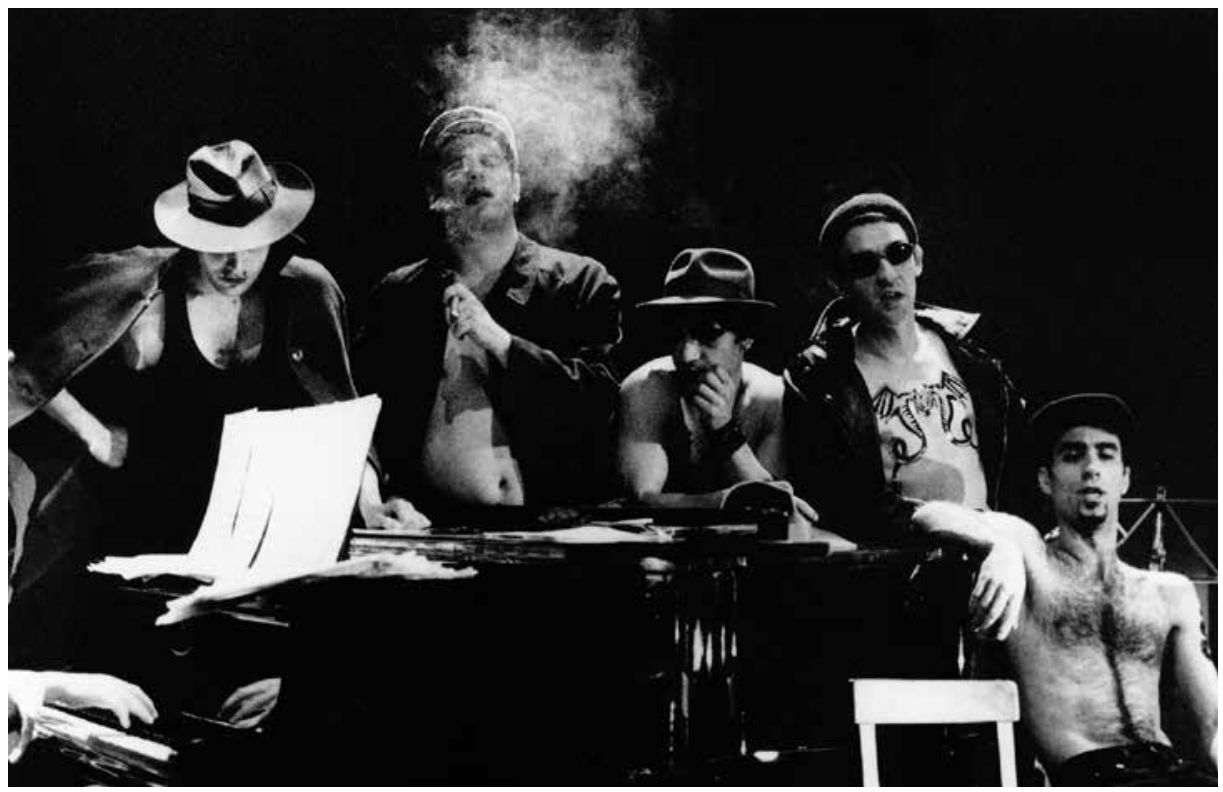

AOS QUE NASCEREM DEPOIS DE NÓS - CANÇÕES DO POBRE B. B., DE BERTOLT BRECHT, ENC. JORGE SILVA MELO, ARTISTAS UNIDOS/COMPANHIA DE TEATRO DE BRAGA, 1998 (BRUNO BRAVO, MANUEL WIBORG, MIGUEL BORGES, JOÃO MEIRELES, PEDRO ASSIS), [F] JORGE GONÇALVES 
Suponho que por causa do meu nariz de judeu e das origens portuguesas do Espinosa. Ele não tinha pensado em mim. O autor da peça, que era um pintor chamado Gilles Aillaud, que já morreu, disse que queria escrever a peça se eu fosse lá representar o papel. Fui e adorei fazer. Aquilo correu muito bem, teve muito boas críticas e público e era um espectáculo muito bonito. Depois, houve mais cinco espectáculos que fiz com o Jourdheuil e com o Jean-François Peyret, que trabalhava com ele. O Jourdheuil gosta muito de discutir depois do ensaio até às tantas da manhã. E eu pertencia a essa família, porque ficava em casa dele. Quando vinha do ensaio, ouvia as discussões entre ele e o Jean François. Também não era apenas actor, estava na parte da autoria, do gesto inicial. Partilhava esse gesto inicial. Pouco a pouco comecei a ser só actor nesses espectáculos, arranjei casa própria, não ficava lá as noites. Fiquei muito amigo de um outro actor, André Wilms, e da sua mulher, Évelyne Didi, e ficava em casa deles, adoro-os. Mas comecei a aborrecer-me de ser actor. Não só a vida é uma estupidez, às quatro da tarde já não conseguia fazer mais nada a não ser pensar no espectáculo e ter de ir para o teatro. Chegava ao teatro às cinco da tarde, o espectáculo era às oito e meia da noite. Não tinha nada que fazer. O Wilms é outro angustiado como eu, portanto, saíamos de casa. Não ia ao cinema, não lia livros. A partir do meio-dia era incapaz de ler. Depois, a seguir ao espectáculo tínhamos de ir jantar, comer e beber bem. Achei que era uma vida completamente estúpida. E fui recusando convites de alguns outros encenadores. Só me interessava trabalhar com o Jourdheuil, porque era autor dos espectáculos também. A certa altura, o Jean e o Jean-François separaram-se e eu achei que já não queria participar naquilo e foi na altura em que decidi voltar para Lisboa.

\section{Mas trazes alguma coisa dessa experiência?}

Sim, a experiência foi maravilhosa, percebi finalmente o que é ser actor e foram seis ou sete anos em que fizemos espectáculos em Paris, em Genebra, em Lyon, em Berlim. Representar noutra língua é uma coisa muito... Embora fale muito bem francês, não é a minha língua, se me esqueço de uma coisa não sou capaz de a substituir. Enquanto em português, em vez de dizer «minha senhora» posso dizer «olá», em francês é diferente... embora o espectador não reparasse que eu não era francês, mas não é a mesma coisa. Assim como não sei o sentido da entoação. Sei que em português dizer «hum... talvez» é uma coisa. E dizer «talvez!» é outra. Mas em francês não sei e não posso saber, 
só a vivência... a vida é que permite o sentido da entoação. Ora, é disso que é feito o trabalho do actor. Mas eu ali tinha de me abandonar. Olhe, seja o que Deus quiser. Seja a entoação que for. Aprendi a não maîtriser. Perdi o gosto em dominar o sentido como actor. Enquanto em Portugal queria que as pessoas percebessem exactamente o que eu tinha pensado, em francês... sei lá o que é que eles vão pensar do que eu estou a dizer. O problema é deles. Eu cá estou a pensar que é isto, mas não podia dominar. Esse prazer, que é o prazer, a meu ver, de quem vai dançar a um salão de baile, que é entregar-se à valsa. Quem toca a música são os outros, e eu vou lá entregar-me à valsa dos outros. É o prazer de representar em língua estrangeira. Não vou dominar, não vou ser o patrão do sentido, o maestro da orquestra. Correu bem, tive êxito, fui bem pago, mas achei que já chegava. A última experiência, que foi num Lucrécio muito bonito, A Natureza das Coisas, já foi muito dura. Esta não é a minha vida, vou mas é voltar para Portugal, onde queria fazer filmes e fiz. Só voltei a fazer mais um espectáculo com o Jean, na Alemanha, em Estugarda, e em alemão... um Heiner Müller.

\section{Começaste pelo cinema quando chegaste. Mas fizeste um espec-} táculo na Malaposta, depois na Gulbenkian...

Isso já foi mais tarde. Fiz cinema quando voltei, dei aulas, escrevi argumentos. E a certa altura, encontrei dois actores que me fascinaram, o Manuel Wiborg e a Joana Bárcia, que tinham vinte ou vinte e um anos. Deu-me vontade de trabalhar com eles e aí nasceu a vontade de fazer mais um espectáculo, como esse da Malaposta, em 1994, um Joyce Carol Oates em que entrava o Manuel Wiborg. Houve também umas aulas que dei em Évora, onde conheci o Paulo Claro. Eu em Paris tinha acompanhado de perto a ideia do André Wilms, esse actor de quem gosto imenso, de fazer uma companhia só de actores, que não era companhia, era gente que se reunia uma vez por ano para fazer os projectos que quisesse e que se chamava Actores Produtores Associados. Tinham o apoio do Théâtre de l'Athénée, um teatro importante em Paris, e durante dois meses podiam apresentar lá os espectáculos que quisessem. Peças escritas por uns ou por outros. E eram para aí uns trinta actores. Eu achei que essa experiência dos Actores Produtores Associados podia ser útil para nós e, como fazia cinema e teatro, podia fazê-los numa equipa a que se chamou AU. Foi isso que nasceu em 1995, creio eu. Formalmente em 1996. 
A nossa curiosidade tem que ver justamente com esse momento de transição e de regresso. É sempre difícil sair de um espaço onde se teve o seu lugar...

Paga-se caro!

\section{Então, como foi isso? Como foi voltar a esse território?}

Estive dois anos no total desemprego. Correspondeu a uma Secretaria de Estado de Santana Lopes. Dois anos e meio, na altura do Passa por Mim no Rossio, no Nacional. Nem um artigo para jornal, nem uma tradução, nada. Nada, nada, nada, nada. Até que consegui - eu já tinha escrito o António, Um Rapaz de Lisboa, para televisão, a convite da RTP, mas depois não quiseram fazer - que a Yvette Centeno, que estava no ACARTE, aceitasse a realização de um seminário sobre esses episódios de António, Um Rapaz de Lisboa. Fez-se um seminário em que se escreveu a peça, que resultou num espectáculo produzido pela Yvette. Mas repara, o espectáculo principal desse ano dos encontros ACARTE tinha trinta mil contos de orçamento, o nosso tinha sete mil. Foi mesmo considerado a última das produções. Mas eu tinha de aceitar. O meu valor no tal «mercado» que ainda não existia era de sete mil contos, não era de trinta mil. Mas correu muito bem no Grande Auditório da Fundação Gulbenkian e depois foi reposto no Tivoli graças ao Carlos Avilez, que dirigia o Teatro Nacional e que decidiu integrar essa produção na temporada. Não tinha ninguém que me desse trabalho, porque os meus colegas da minha idade estavam convencidos de que eu estava em Paris. Era o que diziam, e eu estava aqui, na rua da Artilharia 1, que não era Paris, mas pronto. À Glória de Matos, aconteceu-lhe o mesmo quando veio de Inglaterra. Eu interrompi a minha vida, fui ao mar, perdi o lugar.... e é por isso que não tenho teatro. Se vocês pensarem: todas as pessoas da minha idade, cada qual tem o seu sepulcro. Eu não tenho sepulcro nenhum, tenho esta casita arrendada... [risos]

Tiveste de conquistar novamente um espaço. $\mathrm{E}$ essa conquista do espaço também se fez através desse novo modelo de estrutura e de trabalho. Se viesses para fazer uma companhia como o Novo Grupo, o Meridional ou a Garagem, seria muito mais complicado. Foi isso que pensaste?, que havia outra maneira? 
Pensei que havia outra maneira de produzir, de fazer os espectáculos com os actores, também muito inspirado naquilo que me pareceu criativamente mais interessante, naquela década de 1990 em Portugal, que foi a dança. $O$ facto de a dança se produzir irregularmente, não ter carreira normal, poder estrear no ACARTE e depois vir a fazer outra coisa. Basear-se em estruturas muito leves. Foi o que me interessou e era o nosso modelo até chegarmos, em 1999, à Capital. Fizemos três ou quatro espectáculos até lá, e quando lá chegámos foi uma outra mudança. Neste primeiro modelo confiávamos muito nas grandes instituições, Gulbenkian, Teatro Nacional, Culturgest, CCB [Centro Cultural de Belém]. Eram os nossos parceiros, mas era para apresentar espectáculos de três dias, quatro dias. Com O Fim, que foi o segundo espectáculo, fizemos uma tournée extraordinária: num mês fomos a dezasseis cidades. Montar, desmontar com uma equipa mínima. Isto era possível nesses anos, havia uma grande vontade de ver coisas novas. Agora, conseguimos ir a quatro locais durante um ano. E não existiam tantos teatros como agora há. Só que a nossa precariedade tinha um fim à vista. Depois da Expo, já não tivemos produções com as grandes instituições, já tínhamos colaborado com todas. Não havia razão para o CCB querer mais uma coisa minha ou de a Culturgest querer outra. Pensámos: se não arranjarmos um espaço, morremos. Éramos na mesma AU, mas temos de encontrar um espaço para fazer coisas diferentes. Na primeira época dos AU, fizemos duas peças minhas. Três!, três peças minhas. António, O Fim, o Prometeu e o Fatzer. O Fatzer não era meu, era do Heiner Müller e do Brecht, mas são as quatro peças que fiz antes de precisar de um local. Encontrámos aquela fábrica [A Capital], que um dia estava aberta quando por lá passámos e entrámos. O Balsemão era o proprietário, mas estava em curso uma passagem do edifício para a Câmara Municipal de Lisboa. E cedeu-nos aquele espaço enquanto foi dele. A partir do momento em que passou a pertencer à Câmara, foi-nos tirado.

\section{E começaram a pensar n'A Capital como um centro de artes. Queres explicar em que consistia o projecto?}

Era um edifício abandonado que já conhecia por ter trabalhado no jornal A Capital. No dia em que fui preso, a 21 de Fevereiro de 1968, saiu o primeiro número da segunda fase do jornal. Aquilo agora estava tudo abandonado, muito sujo e achei fascinante. Não para fazer os clássicos, nem peças minhas, mas para fazer aquele teatro que estava a nascer no 


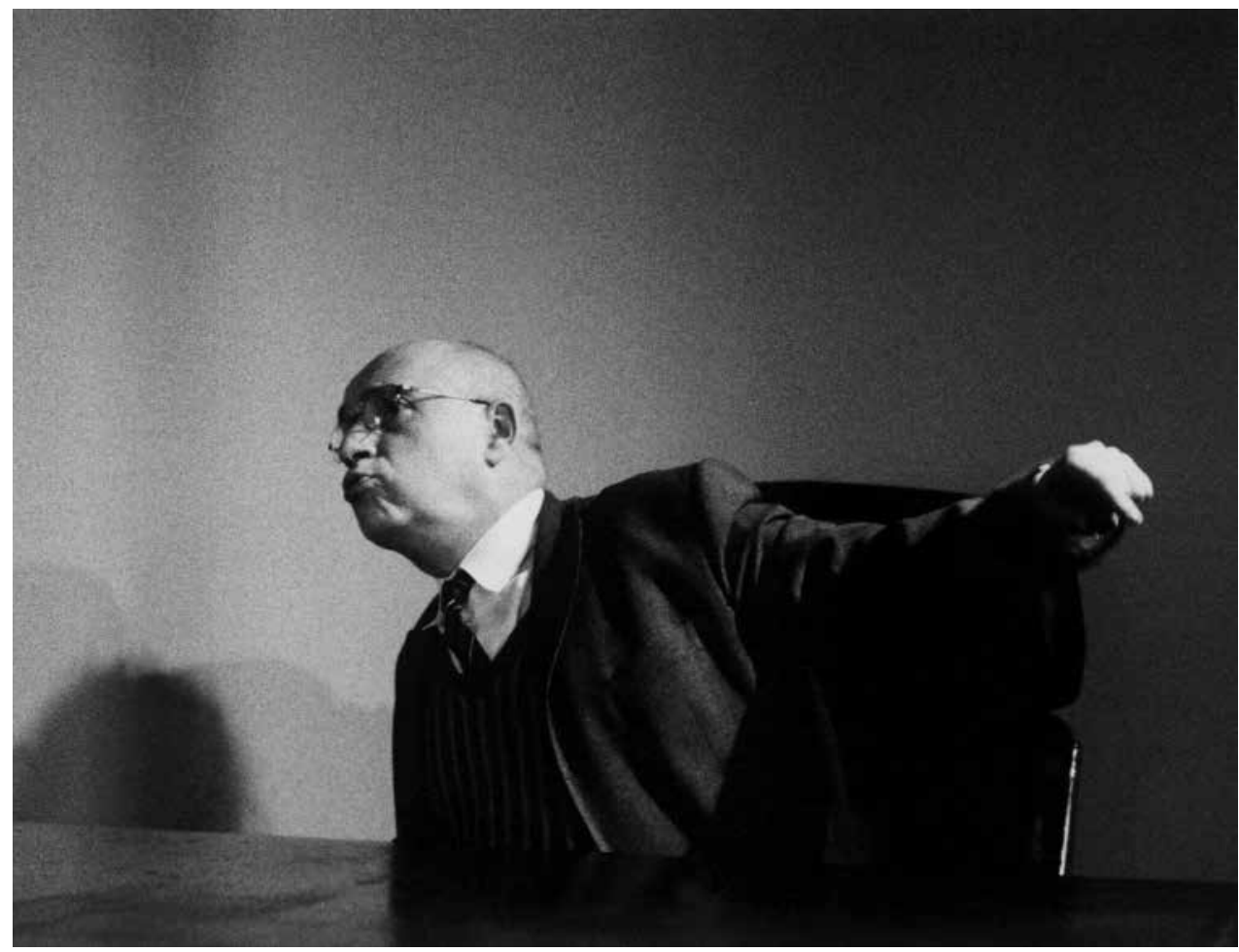

UM PARA O CAMINHO, DE HAROLD PINTER, ENC. PEDRO MARQUES, ARTISTAS UNIDOS, 2002 (JORGE SILVA MELO), [F] JORGE GONCQALVES

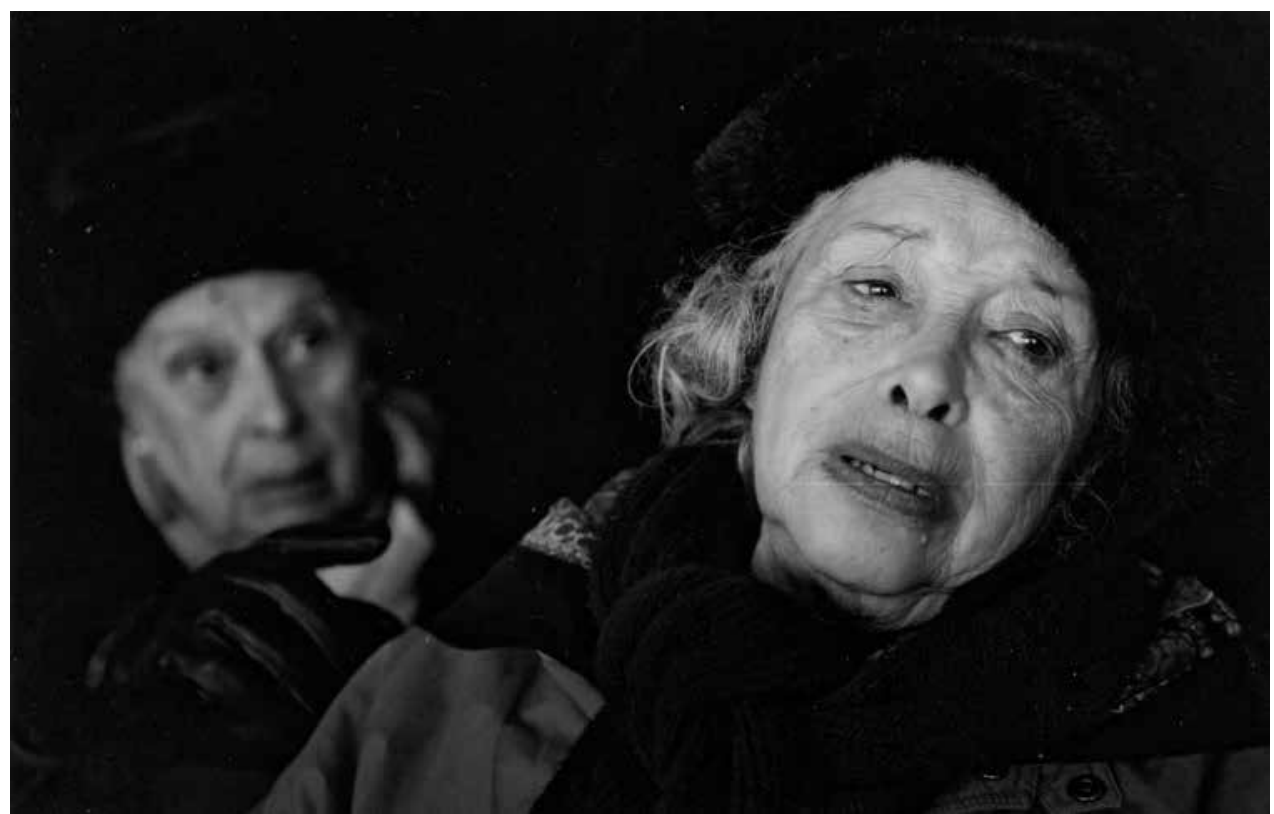

TERRORISMO, DOS IRMÃOS PRESNIAKOV, ENC. JORGE SILVA MELO, ARTISTAS UNIDOS, 2004 (CECÍLIA GUIMARÃES, GLICÍNIA QUARTIN), [F] JORGE GONÇALVES 


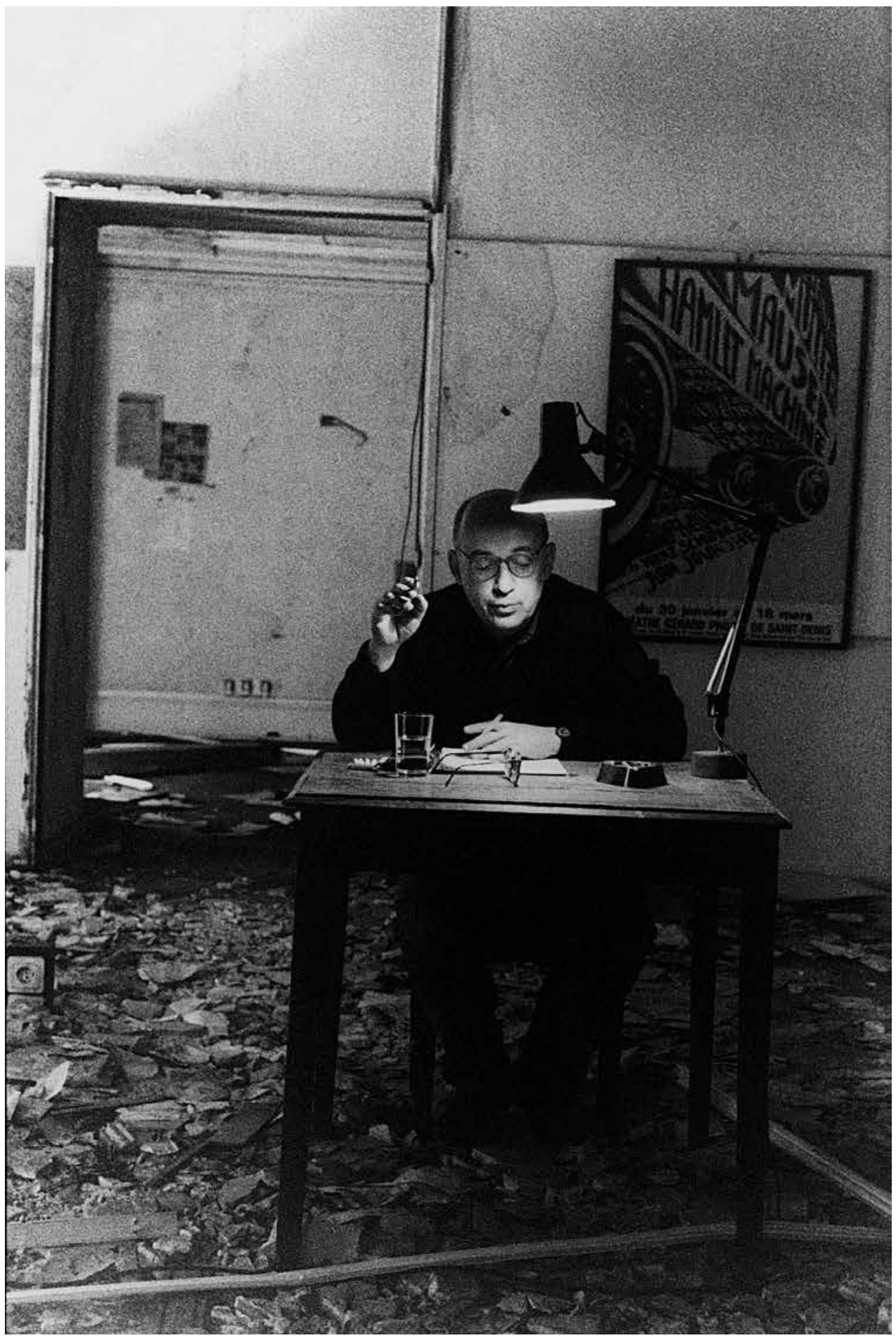

JORGE SILVA MELO LENDO HEINER MÜLLER N'A CAPITAL, LISBOA, 2002, [F] JORGE GONÇALVES 
mundo e algum do teatro que tinha sido pai deste. Eu já tinha lido Sarah Kane. A primeira impressão que tive ao chegar lá foi que $\dot{A}$ Espera de Godot tinha de ser feito naquela sala, mas não me apetecia ser eu a fazê-lo. Perguntei ao João Fiadeiro se o queria fazer, e ele aceitou. Durante o primeiro ano, não fiz lá nada. Só organizei os trabalhos. Funcionei como produtor e tinha um espectáculo de grande elenco na Culturgest, O Navio dos Negros [200o]. Era o último projecto que eu tinha dessa primeira época e que veio a ser feito também n'A Capital. A Capital era a conjugação entre muitos espectáculos pequeninos, de elenco bastante reduzido, que ora ficavam muito tempo em cena, ora ficavam pouco tempo. Havia três sessões simultâneas, mas havia também projectos dirigidos por outras pessoas, como a Madalena Victorino, os actores, a Solveig Nordlund. Várias pessoas dirigiam projectos desafiados por mim, como a Madalena Victorino, que convidei para dirigir Dias Felizes. Ela é coreógrafa e em Dias Felizes a actriz não se mexe. Era um desafio, uma coreógrafa a dirigir um espectáculo em que a actriz não se mexe [risos]. E até conseguiu que ela se mexesse!

\section{Quem é que também veio do cinema, além da Solveig?}

O [Alberto] Seixas [Santos], mais tarde, já no [Teatro] Taborda. N’A Capital estavam lá pessoas do cinema a trabalhar, até o João Pedro Rodrigues andou por lá a escrever o seu primeiro filme. E, claro, a Rita Lopes Alves...

Foi também n'A Capital que se formou uma espécie de núcleo duro de colaboradores que te acompanham ainda hoje. Alguns actores, mas sobretudo criadores de outras artes: Rita Lopes Alves, Pedro Domingos... Como se formou esse núcleo que resistiu até hoje?

A Rita Lopes Alves vem de antes, do meu filme Agosto, que filmámos em 1985. Ela fazia os figurinos - e a partir desse filme fiquei fascinado com o seu saber, a sua sensibilidade, a inteligência. É uma daquelas mulheres práticas e decididas que aprendemos a admirar nos filmes de Howard Hawks, o meu mestre de moral. Sabe tudo, encontra tudo, resolve tudo e tem um enorme sentido da cena. Sem ela, não sei fazer nada. Depois do Agosto, continuámos nos filmes. Mas o seu primeiro cenário foi para a tal peça da Joyce Carol Oates, Greensleeves, que fiz na Malaposta [1994]. E foi aí que encontrei o Pedro Domingos, outro cowboy que tal. Quando digo cowboy, é porque aprendi nos filmes a admirar aqueles homens de poucas 
palavras que sabem qual é o alvo e disparam antes de o adversário atacar. Vem no Ford e sobretudo no Hawks. Não é preciso falar, olhamos em frente e decidimos a mesma coisa. Mas pel'A Capital andavam também o José Maria Vieira Mendes, o Francisco Frazão, o Pedro Marques trabalhando comigo na escolha dos textos... Foram anos grandiosos - e pobres.

\section{A Câmara Municipal de Lisboa inviabilizou o projecto. $O$ que pen- sas que poderia ter sido A Capital no contexto actual?}

A Capital teria sido uma coisa absolutamente fantástica. Eu estaria à frente do projecto e da congregação de esforços daquela gente toda, que eram mais de cem pessoas por dia. Nós estaríamos à frente durante os primeiros cinco anos: dois para as obras mínimas e três de direcção. A partir desse primeiro triénio, haveria concursos para quem quisesse assumir a direcção. Podia ser eu com os AU ou podia ser o João Fiadeiro ou outras pessoas, que concorreriam para um caderno de encargos constituído anteriormente e aprovado pela Câmara e pelo Ministério. Não gostaram da ideia de não ser eu a ficar com aquilo, e de ficar também não gostaram. Mas eu não ficar, acharam todos muito mal. Queriam que ali fosse o meu túmulo. Não passava pela cabeça de nenhum dos poderes da altura - João Soares e Manuel Maria Carrilho - que não fosse o meu teatro. E isso é que era a minha novidade: eu dirigiria aquilo sete anos, se fosse necessário, para instalar o projecto e coordenar as obras, mas o que eu queria é que viesse a servir para outras pessoas. Mas não foi o que inviabilizou aquilo, foi o Manuel Salgado, que não quis que aquilo fosse um teatro. Queria fazer um parque de automóveis, que acho uma coisa muito útil! Mesmo quando as obras foram semiaprovadas pela Maria Manuel Pinto Barbosa, havia dois andares que eram um parque de automóveis e que tinha de ser rentabilizado, que era para... como é que se diz? Para viabilizar o edifício! E com a Câmara do PS [Partido Socialista], continuou o desinteresse. No parque de automóveis entravam seis automóveis; só se pagassem muito dinheiro é que viabilizavam um edifício de cinco mil metros quadrados. Mas enfim... Foi doloroso. Foi muito doloroso.

Quando estávamos a preparar esta conversa, vimos que se entrava no sítio dos AU e há um antes d'A Capital, n'A Capital e depois d'A Capital. De facto, era um projecto agregador, que transcendia os AU.

A intenção era transcender os AU e existir. Os poderes políticos não o quiseram e a partir daí começou uma certa decadência nossa, fomos 
para sítios que detestei, como o Teatro Taborda, onde pagávamos uma renda cara e onde nem sequer a chave tínhamos! Qualquer inquilino costuma ter a chave do prédio. Fomos maltratados. Depois fomos para vários sítios: Convento das Mónicas, etc... Sempre com grande dificuldade em criar relações com os espectadores. Sabiam lá onde é que a gente estava. Foi um tempo muito difícil. Fomos, por vezes, amparados por grandes estruturas, como o São Luiz, e o Jorge Salavisa foi sempre dando a mão a vários projectos nossos. Tínhamos criado um espectáculo chamado O Meu Blackie [2001], n'A Capital, e refizemo-lo no São Luiz. O Stabat Mater [2006], fizemo-lo n'As Mónicas e também o refizemos no São Luiz. O Jorge Salavisa foi sempre apoiando a nossa existência, mas pouco a pouco já não tínhamos sítio onde produzir. Onde é que criávamos as estreias?

\section{Já tinham o espaço da Estrela?}

Não. O espaço da Estrela surgiu quando descobrimos a Politécnica. É o antigo Estrela 6o, que foi da Cinequipa e do Bando até à Expo. Não podemos apresentar lá espectáculos, podemos ensaiar. Não tínhamos sítio. Andávamos desesperados. Às vezes arrendávamos uns sítios fantásticos, outras arranjávamos através de uns ministérios, mas passados seis meses punham-nos na rua. Até que, com o José António Pinto Ribeiro [ministro da Cultura], isto [Teatro da Politécnica] foi encontrado. Naquela altura estava semiarrendado pela Universidade de Lisboa ao Teatro Nacional D. Maria II [TNDMII], num contrato estranhíssimo [risos]. Esteve semiarrendado primeiro ao Inatel e depois ao TNDMII, por inerência de cargo do então director. O José António Pinto Ribeiro conseguiu a reunião de várias vontades, como o Ministério da Ciência de José Mariano Gago e a Câmara, para fazerem obras aqui e para nos fazerem um contrato, que na altura nos pareceu possível e que se revelou absolutamente atroz. Atroz, porque numa das discussões, até foi, acho eu, o José Mariano que disse que a renda teria de ser $9 \%$ do que receberíamos da Direcção-Geral das Artes. Eu não percebia o que queria dizer nem $9 \%$, nem $10 \%$ ou $8 \%$, mas ele é que era de Matemática e do Técnico: $9 \%$. Ficou assim acordada a renda que pagaríamos à Reitoria da Universidade de Lisboa, mas, no contrato, o valor não ficou indexado ao apoio. Ficou fixada a renda num determinado valor. No ano imediatamente a seguir, cortaram-nos o subsídio em 50 \%. Não nos baixaram a renda, porque não consta no contrato a indexação que fora apenas 
falada, embora quase todos os intervenientes se lembrassem desta história dos $9 \%$, mas não tinha ficado escrita. Tivemos de assinar o contrato, porque estávamos, creio eu, em Guimarães com o espectáculo do [Alfred de] Musset [Não Se Brinca com o Amor, 2011] e o contrato ainda não estava assinado e a estreia aqui era para aí uma semana depois. Se não viéssemos para aqui com o contrato assinado...

\section{E foi estreado aqui ou foi em Almada?}

O Musset? Foi o espectáculo que inaugurou o nosso Teatro da Politécnica. Com uma exposição de escultura do Ângelo de Sousa. Fizemos uma digressão bastante grande com o Musset e depois veio inaugurar a sala. Na semana anterior, ainda não tínhamos a certeza de poder vir. Estão a ver o que é a organização económica de uma empresa assim?

Como é que vês, por um lado, essas condições de produção e, por outro, a relação disso com o que nós, espectadores, associamos ao trabalho do Jorge Silva Melo e dos AU: um certo gosto pelo fragmento, pelo inacabado, por uma certa cena suja? Que implicações tem, a determinado momento, a mudança de espaço? Como é que reconstróis aquilo que é o teu foco artístico, o teu modo de trabalhar e de criar as condições de produção para isso?

No momento d'A Capital, é nítido que foram as características muito fortes do edifício que me inspiraram na procura daquelas peças. Quando vou para as Mónicas, é natural que, tratando-se de uma igreja, me inspire a fazer A Paixão segundo São João ou o Stabat Mater, do Antonio Tarantino. O próprio eco da igreja me impelia para estes textos heterodoxos, mas, de certa maneira, religiosos. Quando não tenho sítio nenhum, é como se não tivesse sítio nenhum, portanto estou numa terra de ninguém. Quando venho para aqui [Teatro da Politécnica], tenho grande dificuldade em encontrar um repertório que seja adequado a esta sala, a este bairro e a este público. Este bairro descaracterizou-se como a cidade, e de uma maneira muito rápida. Está numa mutação permanente. A loja mesmo ao nosso lado, desde que aqui estou, já teve seis destinos. São coisas que não chegam a pousar. Enquanto, por exemplo, no início, tínhamos uma grande ligação com as pessoas do bairro, que vinham cá e deixavam a ficha para receber informações, agora desapareceram, tal como os estudantes universitários. Nós temos, para 
as associações de estudantes, um contacto mensal a dizer qual é o nosso calendário, a dar informações e os bilhetes são gratuitos. Mas o contacto perdeu-se e não sei que fazer. Os espectáculos que tiveram mais público são os espectáculos relacionados com escolas, O Rapaz da Última Fila [2012] e o Punk Rock [2014]. Serão os melhores? Ou serão os temas que atraíram uma população constituída por pais, educadores e alunos? Se calhar os professores só querem pensar na escola, não querem pensar em mais nada. Eu pensava que não, eu julgava que queriam pensar em tudo menos na escola. $\mathrm{E}$ os estudantes....

\section{Devem querer pensar nas questões problemáticas que se vivem nas escolas...}

É muito estranho porque foram os dois espectáculos que encheram. Outros tiveram pouquíssimos espectadores e não sei porquê, outros têm a média normal... Será que as pessoas pensam que isto é um teatro juvenil?... Uma vez escrevi uma peça para um jovem de quem gosto muito, o Pedro Gil, dirigir e na qual tinha depositado grande esperança. Chamava-se Sala VIP [2013]. Na altura pensei que era bom um velho a escrever para um novo... Não! Nem os velhos vieram ver, nem os novos. Os velhos não vieram ver porque era um novo a dirigir, não era coisa séria. Os novos não vieram ver porque acharam que ele estava vendido aos velhos. Foi o espectáculo que teve menos gente e é estranhíssimo, nem sequer foi notícia. Foi totalmente ignorado. Temos aqui um grave problema de comunicação com o público! Também corresponde a um momento em que os teatros nacionais e municipais começam a trabalhar com aquilo que poderíamos considerar a nossa esperança de público. Quando os teatros nacionais começam a fazer como produção própria o off, o que é que o off pode fazer? E, neste momento, o Teatro Nacional faz como seu repertório aquele que em qualquer cidade do mundo seria offoff...

\section{Faz aquilo que já existia no Maria Matos e na Culturgest...}

Mas são as grandes instituições que estão a fazer o off, portanto, o que é que nós, pequeníssima instituição, podemos fazer? Que repertório? Porque é que o Pedro Gil não atrai aqui e pode atrair no Teatro Nacional? Porque os lugares são melhores! E porque há uma garantia... 
Talvez porque existe uma máquina de comunicação que é capaz de atrair mais espectadores?

É uma garantia.

Sim, é seguro.

É assim, uma pessoa que vai ver um jovem no Teatro Nacional joga pelo seguro, é bom de certeza... Perdeu-se o risco de descobrir...

Sim, senão não o teriam convidado.

Para ir ver um jovem num barracãozito que está para ali... «Ah, eu daqui a pouco vejo-o no Teatro Nacional.» Já é bom! É uma mudança. A consagração passou a ser o motor. «Ah, isto é bom! Isto aqui tem qualidade. É de primeira classe!» Não vão ver as coisas de terceira categoria porque as pessoas têm de contar o dinheiro que gastam.

\section{As questões do público são muito complicadas. Parece que se criou um circuito obrigatório e ou se está dentro dele ou não.}

Sim, mas são trezentas pessoas. Enquanto o Teatro Nacional foi dirigido pelo Diogo [Infante], houve uma abertura. Chegaram a fazer espectáculos aos quais chamaria comerciais, tentando cumprir o que acho ser obrigação de um Teatro Nacional: difundir. Agora é ao contrário. O que existe é reduzir o espectáculo a um público de profissionais do meio. Se fazem um espectáculo para duas ou três representações, está-se a dizer que aqui só podem vir as pessoas que fazem este espectáculo ou os que querem vir a fazer. É o contrário da missão, a meu ver, de um Teatro Nacional. Neste momento o teatro que está a ser feito é para colegas ou aspirantes a colegas. Neste momento é festivo, tudo é festivo. É muito triste que o destino do dinheiro público seja para satisfazer as festas de anos de duzentas pessoas. $O$ regime artístico do evento. A cultura do evento. E é a estética da festa de anos, ou seja, um bocadinho de disparate, um bocadinho de sentimentalismo, que já nos conhecemos há muitos anos, uns beijinhos, mas, sobretudo, umas palhaçadas a fazer troça, que é o que nós fazemos nas festas de anos. Ou nos antigos «assaltos de Carnaval»... 


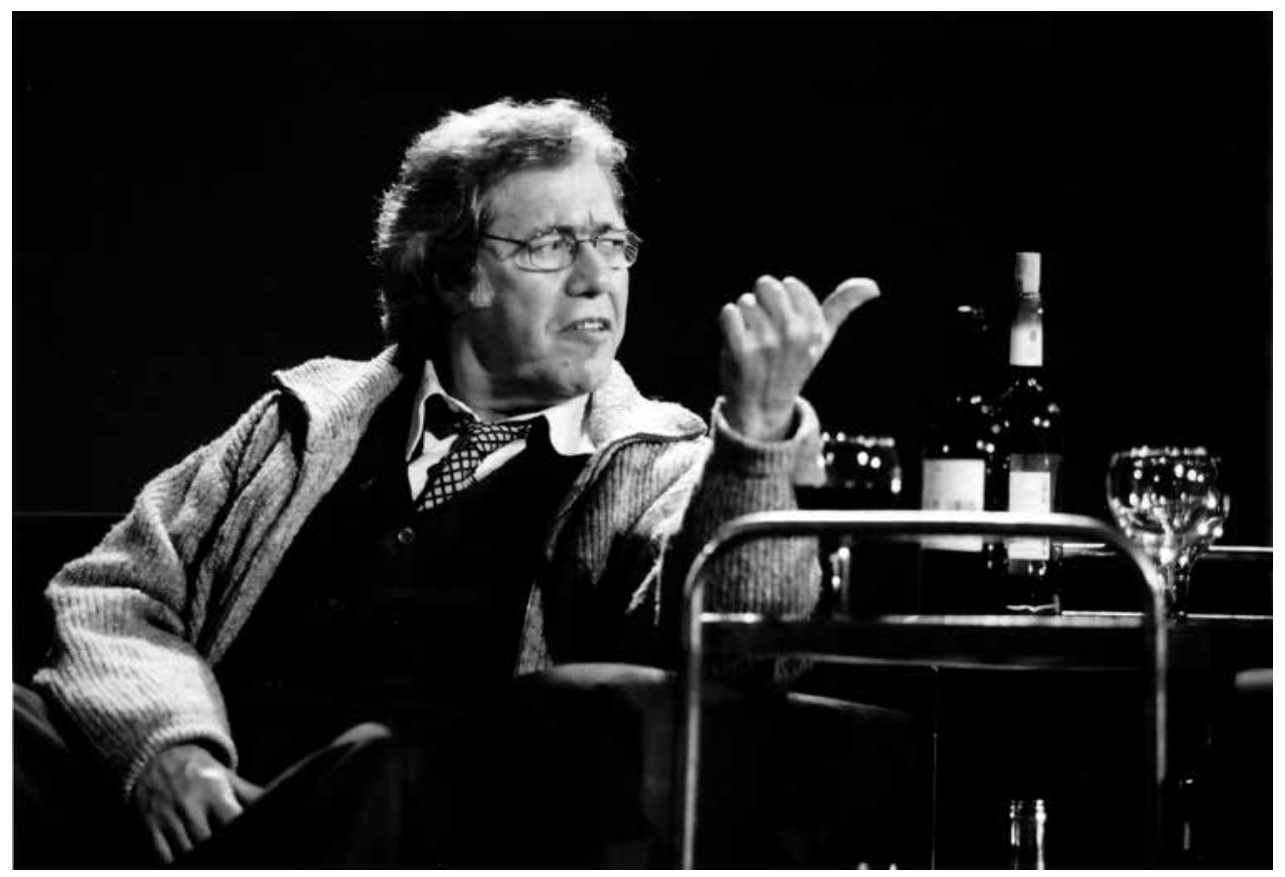

ONDE VAMOS MORAR, DE JOSÉ MARIA VIEIRA MENDES, ENC. JORGE SILVA MELO, ARTISTAS UNIDOS, 2008 (SÉRGIO GODINHO), [F] JORGE GONÇALVES

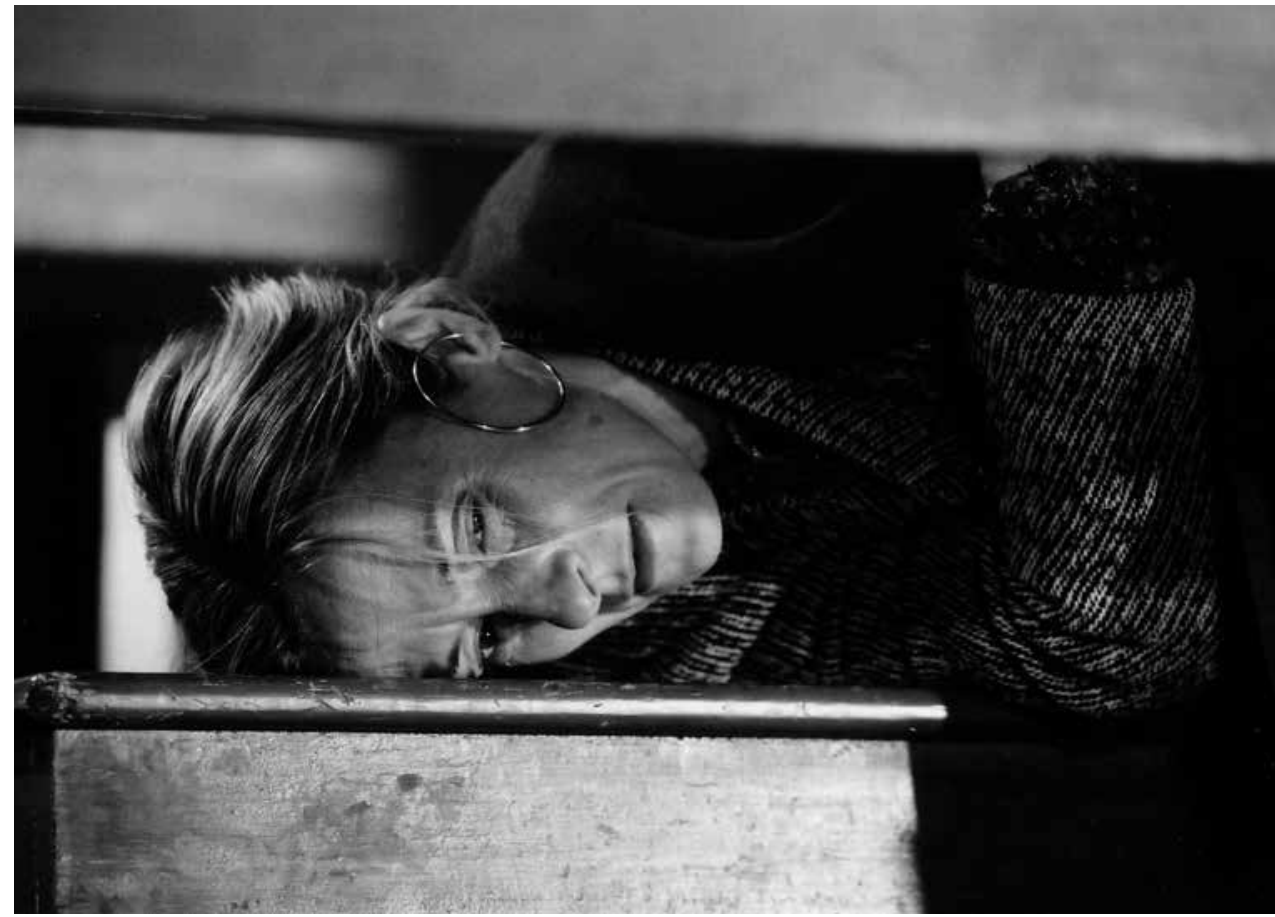

STABAT MATER, DE ANTONIO TARANTINO, ENC. JORGE SILVA MELO, ARTISTAS UNIDOS, 2006 (MARIA JOÃO LUÍS), [F] JORGE GONÇALVES 


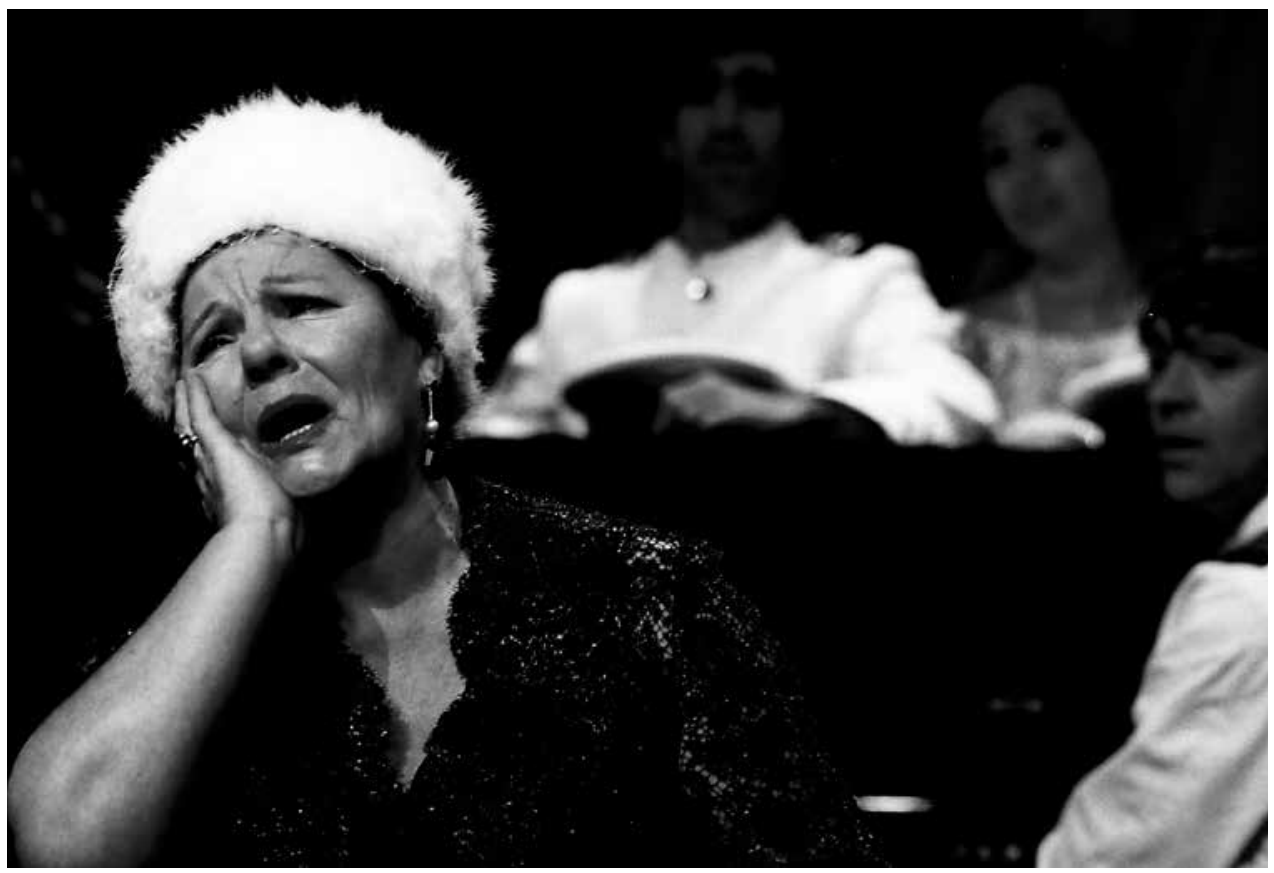

ESTA NOITE IMPROVISA-SE, DE LUIGI PIRANDELLO, ENC. JORGE SILVA MELO, ARTISTAS UNIDOS, 2009 (LIA GAMA), [F] JORGE GONÇALVES

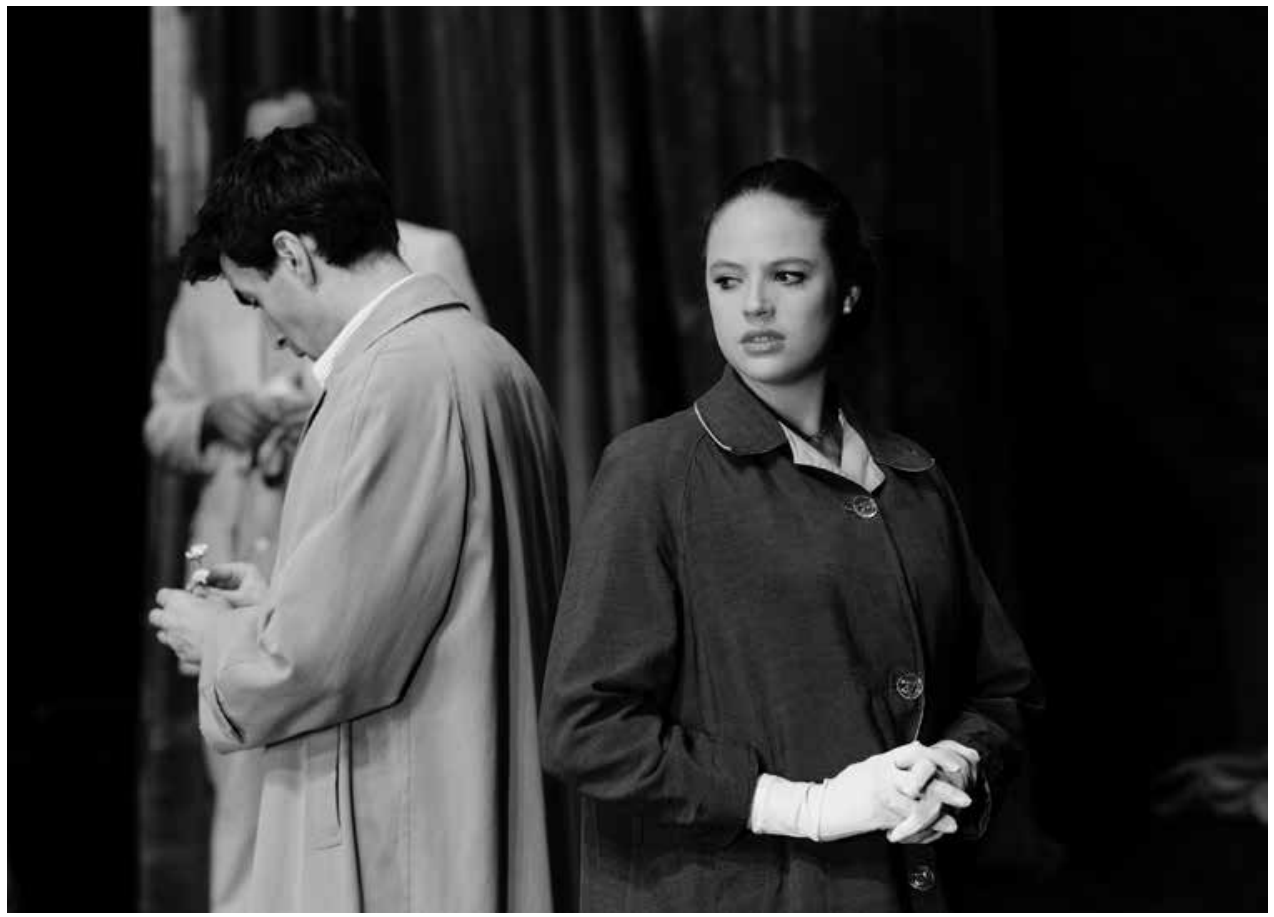

NÃO SE BRINCA COM O AMOR, DE ALFRED MUSSET, ENC. JORGE SILVA MELO, ARTISTAS UNIDOS, 2011 (ELMANO SANCHO, CATARINA WALLENSTEIN), [F] JORGE GONÇALVES 
Voltando aos AU. Agora neste espaço continuam com um foco na contemporaneidade, embora encenando também os clássicos da modernidade do teatro. Nós pensamos que há essencialmente três pilares que os AU comunicam a quem acompanha o vosso trabalho. Três pilares que têm uma tradução em três aspectos importantes na organização do vosso trabalho. Os textos: temos os livrinhos de teatro, que são, por um lado, registo do que é feito e a tal proposta...

... para que outros façam.

Os actores... Quando aparece o cartaz e os materiais de divulgação, são os actores em primeiro plano.

Sim, é um ponto de honra!

E talvez o terceiro pilar seja a organização do trabalho, a forma como se trabalha aqui e que é provavelmente diferente dos outros teatros...

O facto de eu ter sido actor, privilegiado, em França e na Alemanha, faz-me pensar: que pena este actor de quem gosto não ter tido o desafio que eu tive. Interessa-me imenso dar aos actores de quem gosto - e acredito que a arte do actor é uma arte superior - papéis que eles podem fazer e não sabiam que podiam. Interessa-me imenso dizer: «Rúben, tens aqui este papel para ti», «Maria João Luís, tu detestas esta peça, mas este papel é para ti. Sem ti, não faço», «Nunca li essa peça, nem quero ler!», «Está bem, mas fazes!» Interessa-me que os actores possam ter o seu momento de esplendor comigo e sei organizar o trabalho para que isso aconteça. Tenho a honra de ter tido junto a mim actores fantásticos que estão já noutros sítios e noutras paragens, com quem volto ou não a trabalhar, mas honro-me de ter marcado o trabalho deles, dando-lhes papéis que provavelmente ninguém lhes daria nem eles, se pensassem, iriam escolher. Isso condiciona a minha escolha do repertório. Quando escolho peças, penso sempre: «Isto é para que actor? Tenho actores para isso ou não?» Por exemplo, agora estou com um problema económico. Para o ano há uma peça que eu gostaria muito de fazer e que tenho adiado. $\mathrm{O}$ elenco que tenho agora disponível está mais velho do que seria ideal para essa peça. Estou a adiá-la para aí há oito anos. Neste momento têm quarenta e cinco anos 
as pessoas que tinham trinta e cinco ou trinta e sete. Posso contar com eles? Ou é melhor chamar outros? Não tenho dinheiro para chamar outros, mas estes não estarão já velhos demais para este momento? É um dos dilemas que tenho de resolver amanhã. Esta peça tem nove actores. Não sei se cabem nesta salinha. E também tenho razões económicas para ponderar. Ao mesmo tempo é uma peça tão experimental que não há nenhum teatro em Lisboa onde eu a possa colocar. Nem o São Luiz, nem o D. Maria a aceitavam. O que é que eu faço? Desisto de fazer a peça por ter actores velhos demais? Não a faço aqui porque é um desperdício económico? E como esta há várias... Neste momento, os teatros importantes, como eu sou velho, querem que eu faça clássicos ou comemorações, como os duzentos anos de não sei quantos... Estou com este problema e essa peça, se calhar, perdi-a para sempre. Não vou ter dinheiro para fazer outra companhia enquanto estes ficam a chupar no dedo. Em princípio, não abandono actores de quem gosto e gosto de lhes dar trabalhos cada vez mais difíceis.

\section{Desafiá-los...}

Prefiro fazer uma peça para um actor certo, do que fazer uma peça de que goste muito. Prefiro ter o actor certo e dar prazer ao actor do que estar a fazer uma peça com alguém que não conheço. Isso não me interessa quase nada.

\section{Mas vais buscar actores de quem gostas muito para se juntarem aos jovens... a Mariema... a Lia Gama...}

A Joan Littlewood, que foi a maior encenadora que existiu no mundo, dizia (ela tinha uma companhia): "Tenho sempre de chamar um para cada novo espectáculo, senão isto fica uma família e eu detesto famílias! Já tenho a minha e não gosto dela.» Trata-se de haver um novo equilíbrio com a chegada de uma pessoa nova. Diz-se adeus a um, mas aparece outro. Ainda agora, no Jardim Zoológico de Vidro [2016], apareceu à última hora um actor de quem gostei imenso, o José Mata, eu tinha-o visto numa peça do Oscar Wilde.

\section{Sabemos que foste professor na Escola de Cinema.}

Sim, fui durante bastante tempo e gostei muito de o ser. 


\section{E então? Não é compatível com fazer teatro ou filmes?}

Não! Na Escola de Teatro nunca fui convidado. Na Escola de Cinema fui professor. Mas gostava demasiado dos meus alunos e odiava despedir-me deles. Alguns dos meus alunos foram o Manuel Mozos, o Edgar Pêra, o João Pedro Rodrigues, com quem vim a trabalhar profissionalmente. Escrevi argumentos para o Manuel, trabalhei com o Edgar em várias coisas, e o João Pedro Rodrigues foi meu assistente de realização e sócio dos AU desde o início. Criei relações extracurriculares com os meus alunos. Ora, isso não pode ser! Acaba o último ano lectivo e «adeusinho, vão lá à vossa vida!». Mas eu não, fui «mamã» daqueles alunos. A minha vontade de ser vampiro, de sugar o sangue dos mais jovens, é isso. Gostei de trabalhar com eles e de juntá-los. O meu ideal provavelmente é até a oficina do pintor renascentista, que tem lá vários aprendizes. Há um que sabe fazer passarinhos, outro que sabe fazer nuvens. «Façam lá as nuvens, que eu agora vou namorar e tenho de escrever seis sonetos!» Era esse o meu interesse na vida, que o teatro fornece, porque tem a vantagem de ser uma actividade que reúne pessoas de muitas profissões diferentes, com saberes diferentes, e que os congrega todos: às nove da noite sobe o pano para todos nós, bilheteiros e autores.

\section{O cinema funciona de outra maneira...}

O cinema é uma arte de grande isolamento para o realizador. $\mathrm{O}$ teatro é uma arte de convívio total. Quando ando mais solitário gosto de fazer cinema, quando me sinto mais sozinho quero fazer teatro para ter mais pessoas à minha volta. No cinema escreves o argumento com uma pessoa, depois vais negociar esse argumento com o produtor e vais trair a pessoa com quem escreveste o argumento, porque vais deitar fora as cenas que aquela queria e que o produtor diz que são muito caras. Depois conversas com o produtor e começas a trabalhar com os actores e com o director de fotografia. Chegas à montagem e vais trair os actores, porque vais estar só com o montador. «Ai que feio que aqui está!», «Aqui pôs a língua de fora. Que coisa horrível! Vamos cá substituí-lo. Em vez deste plano que tivemos tanto esforço a fazer, vamos fazer com outro...» Mas tu estás sozinho com o montador. Já não estás nem com o escritor do argumento, nem com o produtor. Estás sempre sozinho até à estreia, onde já não há nem actores, nem director de fotografia, porque estão todos já a fazer outra coisa. É uma espécie de teimosia, uma obstinação insensata 


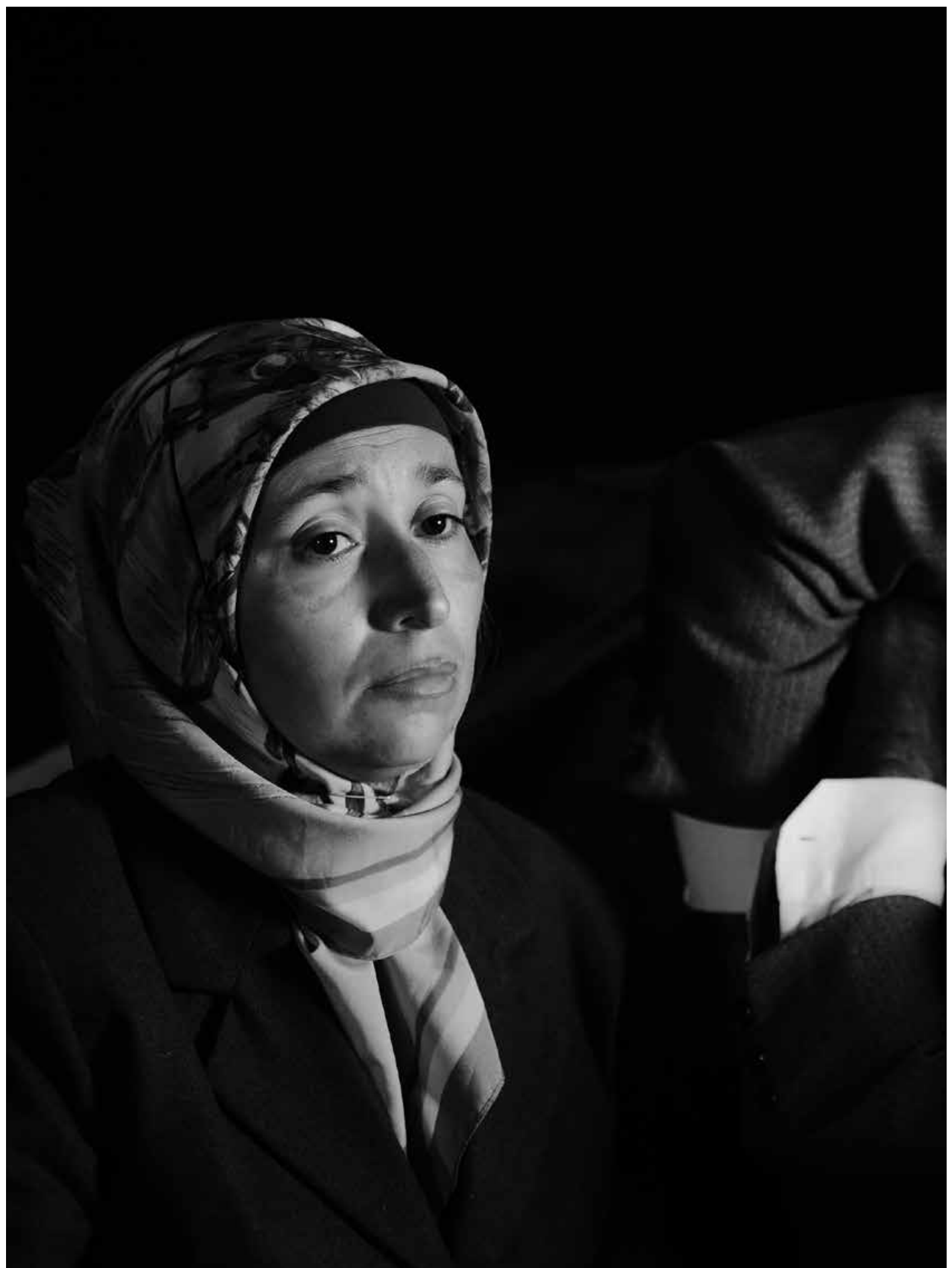

A CASA DE RAMALLAH, DE ANTÓNIO TARANTINO, ENC. JORGE SILVA MELO, ARTISTAS UNIDOS, 2014 (ANDREIA BENTO, ANTÓNIO SIMÃO), [F] JORGE GONÇALVES 
de levar até ao fim o projecto, e aí o [Manoel de] Oliveira era genial. $\mathrm{O}$ teatro não é isso. $\mathrm{O}$ teatro é toda a gente ao molho e fé em Deus e chega-se à meia-noite do último dia e acabou.

Tudo começou com a paixão pelo cinema. Falavas, logo no início, da herança do teu pai, que não se apagou. Continuas a fazê-lo, mas de outra maneira, na ligação com as artes plásticas e com os artistas de que gostas muito... Mas o cinema não estará no teu olhar sobre o teatro?

Sim. No cinema, a primeira coisa que me atraiu, como a qualquer pessoa, foram os actores. Sei que um dos primeiros filmes que vi foi com a Anna Magnani chamado A Zaragateira, do Luigi Zampa, quando tinha cinco anos ou coisa parecida... Foram os actores, aquelas pessoas lindíssimas, que me fascinaram. Aquela presença maior que a vida. Da minha experiência como realizador, ficará sempre uma espécie de capacidade de decisão. Faço os ensaios mais curtos da maior parte dos encenadores que conheço. Duas, duas horas e meia e acabou-se, porque adoro decidir no momento e não arrastar. Agora parei os ensaios durante uma semana, porque os actores estavam a fazer bem, mas não havia estímulos de fora. Para mim, cada ensaio tem de ser, não um ramerrame ou uma rotina, mas um acontecimento novo, e eu, por obrigação, tenho de dar aos actores condições para que eles cheguem à estreia descansados. Acho que consigo fazer isso. O meu objectivo é que os actores cheguem à estreia confiantes de que o trabalho está bem feito e que agora estão capazes de desenvolver o que fizeram. Nunca vejo os espectáculos depois do ensaio geral. A partir daí é da responsabilidade dos actores responderem ou não ao contrato que foram estabelecendo durante os largos meses de ensaio, ainda que os ensaios sejam curtos; duas horas e meia, três. Por exemplo, esta peça que estou a fazer, $O$ Rio, tem uma hora e meia e eu raramente ultrapassei as duas horas e meia, três, de ensaio. Não gosto de estar ali a engonhar, gosto de tomar as decisões e gosto que os actores tomem as decisões como o toureiro. Vem aí o touro, tenho de resolver o assunto.

Tínhamos falado na questão da linhagem, uma expressão muito engraçada que usaste uma vez, numas palestras para que te convidaram, na Culturgest, não sei se te lembras... Estavas a falar da [Marie] Hélène Dasté e do [Jacques] Copeau e deste muito relevo 
a esta questão, que para ti era muito importante, de haver uma espécie de linhagem, de famílias no teatro.

Sim.

E depois, noutra conversa na Faculdade de Letras [da Universidade de Lisboa], a propósito das imagens que ficam de um espectáculo, disseste que a História é uma história e não diz o que foi o teatro. Como é que tu pensas essa questão de linhagem - se é que a pensas - no que vais fazendo com os actores que vão passando por aqui? E há pouco estavas a dizer que ficas contente por tê-los encaminhado e eles depois fazem os seus grupos, os seus trabalhos. É essa ideia de linhagem que está presente no que tu queres que fique daquilo que fazes?

É! Gosto imenso! Houve duas coisas que me orgulharam muito. Uma é, em Setembro [de 2017], irmos ler para a rádio - que é uma coisa que fazemos também - Os Dias Inteiros nas Árvores, de [Marguerite] Duras, na tradução que foi feita pelo José Lima, para Almada. Com a participação de Cecília Guimarães, uma actriz de oitenta anos que adoro e que criou o papel em Almada. O João Meireles dirige, a Cecília Guimarães faz a Mãe, a Vânia Rodrigues, o João Pedro Mamede e o Nuno Gonçalo fazem os mais novos, muito mais novos do que as personagens, mas na rádio não se nota. Gosto imenso que uma actriz de oitenta e tal anos possa estar a contracenar e a ter medo, ao mesmo tempo que actores de vinte e poucos que nunca tinham ouvido falar dela, porque ela é uma actriz, infelizmente, muito esquecida... E é uma grande actriz! Claro que esta troca se consegue mais na conversa de camarins do que nas aulas. Se estou a maquilhar-me, se sou velho e estou ao lado de um actor novo, conto muito mais histórias do teatro do que outras pessoas. Gosto de contar isso e gosto de contar as histórias do Strehler, do Peter Stein ou do Jean Jourdheuil ou as minhas próprias velhas histórias. Infelizmente esta sala não permite isso. Gostava de ter um teatro onde pudesse chamar a Cecília Guimarães ou a Lia Gama para virem fazer uma peça e ter um jovem actor misturado com elas. Há repertório para isso, mas esta sala não permite essa presença. É uma coisa que o Arthur Miller conta com imensa graça na autobiografia dele, Timebends, um livro maravilhoso. Quando começa a escrever peças, pensa em personagens mais velhas do que ele, como A Morte de Um Caixeiro Viajante [1949], 
cujos protagonistas eram bem mais velhos do que ele na altura. Mas, quando ele tinha sessenta anos, não havia nenhum actor na Broadway com aquela idade que aceitasse dois anos de contrato. Estavam todos a ir para Hollywood.... O Lee J. Cobb, quando fez A Morte do Caixeiro Viajante, era mais velho que o Miller e aceitava. O Miller tinha de escrever peças para jovens actores, que, ainda por cima, nunca estariam dois anos em cena, porque, por serem novos, eram pouco conhecidos e nunca teriam público suficiente para ficar em cena como as grandes vedetas. O Lee J. Cobb ficava dois anos em cena, com espectáculo todas as noites. E o Miller, no fim da vida, dizia «Não consigo pôr em cena uma personagem que tenha a minha experiência de vida. Só consigo imaginar o que um jovem estará a sentir neste momento.» E é verdade. Se eu agora escrever uma peça para contar a minha experiência de vida, quem é que a vai representar? Com a minha idade ainda conseguem decorar um texto?

Ainda há pouco falavas do que é ser contemporâneo, do que está a acontecer agora. Vais buscar um clássico que queres que fale de hoje, de coisas que para ti são importantes, mas para os jovens também. Nessa criação de linhagem, o que estás a dizer, se bem entendo, é que fazes a ligação. Constróis o discurso que liga a tua experiência à deles.

Claro! Mas não posso escrever uma peça para um actor de setenta anos. Já somos poucos e estamos cansados. Quando muito, posso escrever uma peça para um actor de quarenta anos, mas não sei o que é que uma pessoa de quarenta anos neste momento pensa da vida, vai ser imaginado. A condicionante do teatro é ter de escrever para agora. Não posso escrever para daqui a duzentos anos, não é? Enquanto no cinema posso escrever um papel para um homem de setenta anos, porque talvez consiga encontrar, mesmo com muito cuidado, um actor; no teatro já pouquíssimos actores dessa idade conseguem aguentar o ritmo. É demasiado duro. $\mathrm{E}$ há muito poucos. Três ou quatro, mas são muito poucos.

Notas nos teus actores um grande desfasamento na formação? A formação cultural, que é esta cultura urbana de hoje, dificulta estar e fazer teatro com eles, entusiasmá-los para as escolhas de repertório que fazes? Eles próprios trazem-te textos que acham interessantes? 
Cada vez menos. Cada vez é maior a distância de idades entre mim e os actores mais novos. Reparem, quando estava n'A Capital, tinha quarenta e cinco anos e os actores com quem trabalhava tinham trinta. São quinze anos de diferença. Agora tenho sessenta e oito e trabalho com actores de vinte. Sou avô! É muito difícil um actor de vinte dizer-me a mim: «Ah, essa peça não presta e eu não quero fazer.» Mesmo que não gostem, coçam a cabeça para perceber porque quero essa peça. Há uma atitude de reverência que já não é a mesma atitude de quando estava n'A Capital. Essa desapareceu para sempre e desaparece com a idade. Trazerem-me peças, sim! O João Pedro Mamede vai-me trazendo propostas e eu vou fazendo. Aquilo que me entristece é que aquelas que eu trago vencem... E é por causa da idade, de eu ser mestre, de ser autoridade. As propostas que eu faço acabam por ser mais realistas, mais adequadas à experiência da companhia. É todo um novo caminho...

\section{Outra questão é o teu gosto pela tradução...}

Gosto imenso de traduzir, é uma coisa que me encanta. É uma primeira arte de actor. Eu fiz muitas. Escrevi argumentos para cinema e também essa interpretação do desejo de outro é uma arte de actor. Estava ali o dia todo a escrever e vinha o realizador ao fim da tarde: «Que tal?» Era como se estivesse a ensaiar e eu só queria que ele dissesse bem de mim. Tal como o actor. É a mesma arte de sedução e de trabalho interior que tinha de fazer para o tal olhar do outro. Traduzir para o teatro é brincar com a língua; um jogar com a língua de uma maneira inventiva e é bom quando consigo libertar-me do original. Quase consigo escrever «à maneira de». É quando fico mais contente, quando já não sei o que é que ele escreveu e escrevo por mim próprio. Gosto muito de encontrar algumas soluções. O Novo Dancing Eléctrico [de Enda Walsh] tinha alguns problemas que eu não conseguia perceber. Estava muito bem traduzido pela Joana Frazão, mas, ao ver os actores a representar, deixava de perceber a peça e consegui encontrar soluções para os três momentos mais difíceis, porque uma palavra tinha acento na primeira sílaba e era importante que tivesse na última para poder ser uma palavra bem ouvida. Era «quebra», e «quebra» ouve-se qué-. Ai que grande qué-... e eu não percebia o que era. Era uma palavra muito importante para a acção e repetida várias vezes. Gosto muito de encontrar no texto as soluções, porque há um lado técnico no teatro, no cinema e na pintura que me encanta, uma peça é um problema que tem de ser resolvido, tal como numa canalização. Tem de ser 


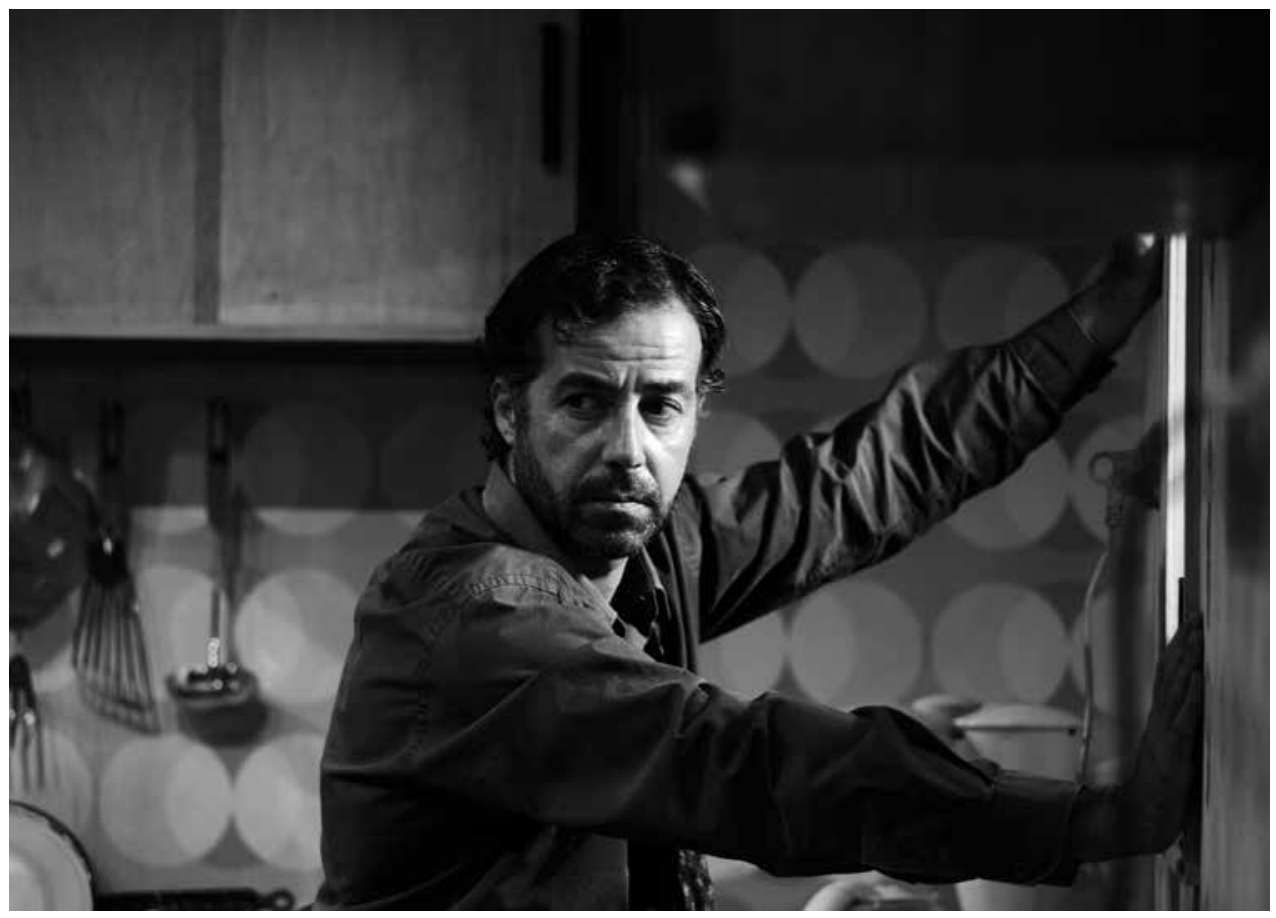

JOGADORES, DE PAU MIRÓ, ENC. JORGE SILVA MELO, ARTISTAS UNIDOS, 2015 (PEDRO CARRACA), [F] JORGE GONCQALVES

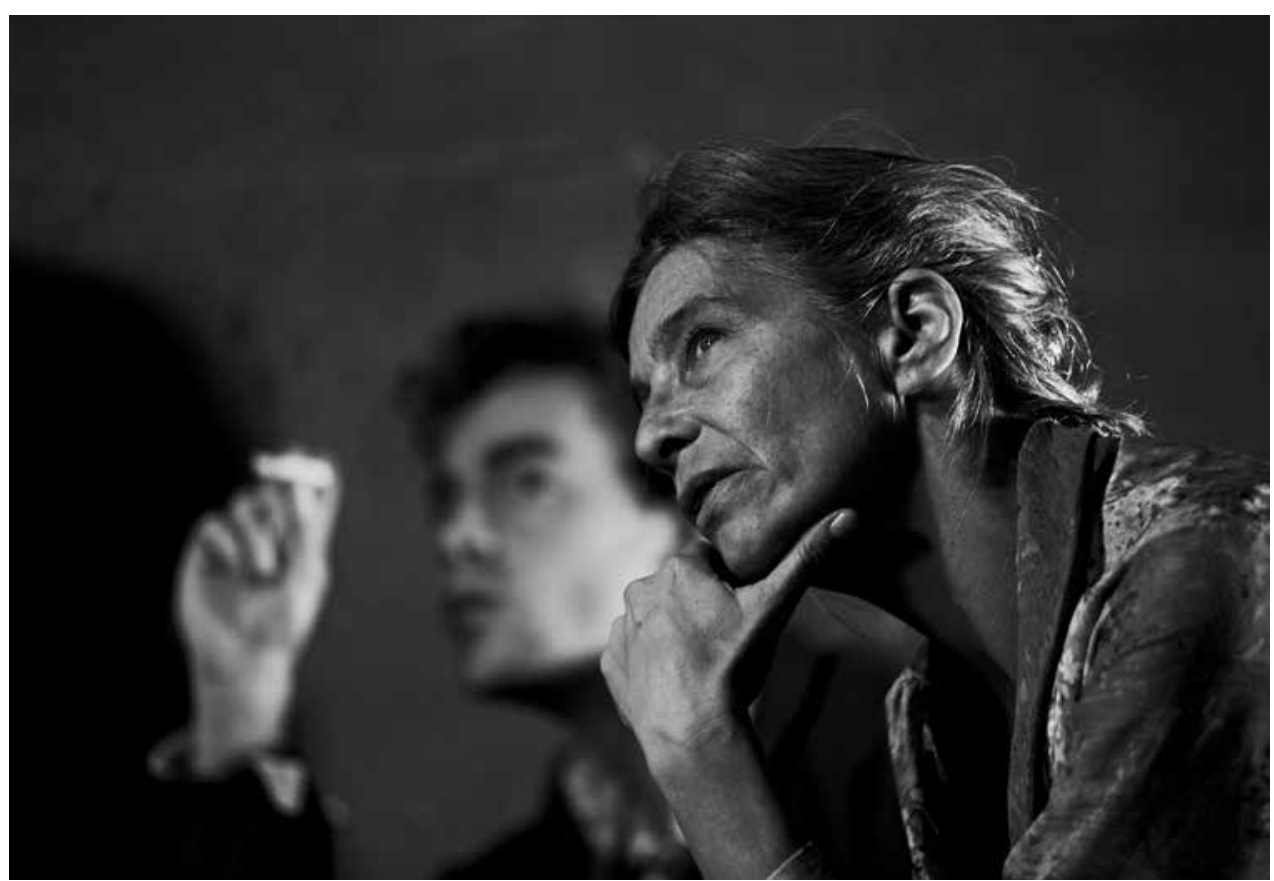

JARDIM ZOOLÓGICO DE VIDRO, DE TENNESSEE WILLIAMS, ENC. JORGE SILVA MELO, ARTISTAS UNIDOS, 2016 (JOÃO PEDRO MAMEDE, ISABEL MUÑOZ CARDOSO), [F] JORGE GONÇALVES 
resolvido este problema, e a própria peça é que nos vai dando ordens. Houve uma de que me orgulhei imenso... Em O Quarto [1957], há uma personagem que se chama Mr. Kidd e há outra personagem que está sempre a dizer: «Yes, Mr. Kidd! Yes, Mr. Kidd!». Quando se diz Mr. Kidd em inglês e em voz alta, ninguém repara que tem dois dd. Pensa-se que é o Sr. Novo, mas, quando se diz em português, como está na edição, «O Sr. Kidd, o Sr. Kidd»... E eu ouvia a Lia [Gama] dizer «o Sr. Kidd, o Sr. Kidd» e pensei que não podia ser. Temos de perceber que este homem é um bocadinho infantil ou que ela o vê um bocadinho infantilizado, mas com o «Sr. Kidd» não vamos lá. Numa noite, descobri, «Sr. Júnior»! Não é a mesma coisa, nem Júnior pode ser um nome de família, mas fiquei absolutamente radiante e contei à viúva do Pinter, a escritora Antonia Fraser: «Olhe, fiz uma traição, mas acho que consegui apreender a ideia.» Porque na tradução no teatro, e em determinados autores de que gosto, o duplo sentido é fundamental. Mesmo que não seja o duplo sentido original, não quero perdê-lo.

\section{Portanto é, na verdade, o prazer do trabalho com as palavras...}

É o prazer do trabalho do intérprete. O tradutor é um intérprete, tal como $o$ actor.

\section{Também foste crítico. Como encaras a crítica hoje?}

Fui e gostei muito de ser. É uma pena a crítica ter desaparecido do dia-a-dia. Neste momento só existe como espaço de classificação por estrelas. Não existe reflexão crítica nem imprensa que a deseje. É uma pena: o espectador normal deixou de ter informação, deixou de ter convite a pensar. O convite a pensar de outra maneira. É pena! E é curioso, por exemplo, na ópera há crítica. Ora, a ópera tem menos sessões do que um espectáculo de teatro. Mas porque é que na ópera há crítica?

\section{Porque os jornais ainda criam espaço para ela...}

Porque os jornais precisam de subir socialmente. «Estivemos na mesma noite dos banqueiros. Na ópera. Que bom! E ela cantou maravilhosamente!» Os jornais precisam dessa ascensão social, que o teatro não permite. É classe média baixa... 
É muito complicado. Agora existe só na Internet, que é outra coisa...

Pois, agora há na Internet, mas perdi o rasto.

Porque é que abandonaste as crónicas? Porque também já não há espaço nos jornais?

Porque não quiseram. Escrevia crónicas para o Público, e a certa altura o suplemento em que escrevia acabou e pronto.

Portanto, é novamente uma questão de estrangulamento de espaço de discussão...

Não querem mais.

\section{Mas ainda faz sentido para ti escrevê-las?}

É uma coisa de que gosto imenso de fazer. Uso o Facebook para fazer o que ainda me resta de gosto pela escrita. Gosto de reflectir sobre a actualidade e de misturar coisas. Mas não quiseram mais. Aliás, nem me disseram nada! Que é a boa educação do costume.

Sobre Portugal no pós-25 de Abril, escreveste numa das crónicas, se não estou em erro: «Nada disto é o que quis que fosse.» $O$ que querias que fosse?

Sim, não gosto do Portugal depois do 25 de Novembro. Depois do 25 de Novembro não gosto nada.

\section{O que era para ser foi muito curto.}

Foi muito curto e não chegou a ser... Não chegou a ser a partilha, a discussão, a oposição. Durante a Revolução opus-me aos preceitos estéticos do Partido Comunista Português (PCP) (e, já agora, também da UDP e do PS). O PCP queria as grandes instituições, o Teatro Nacional, os grandes centros dramáticos e eu era contra. Queria um teatro independente, que acabei por fazer, mas opunha-me a essa estatização pindérica e infeliz do teatro que acabou por acontecer. No outro dia escrevi isso no Facebook... Havia aquelas récitas de teatro francês que vinham 
ao São Luiz quando eu era adolescente. Eram tournées de espectáculos comerciais que faziam em França, depois havia um empresário que os comprava. Eles iam para Marrocos e na passagem para Casablanca paravam em Lisboa. Faziam dez espectáculos por ano e era um público ridículo de senhoras que nem sabiam francês, mas que tinham casacos de peles para estar lá sentadas. Agora o teatro é isso. Só que as senhoras já não falam francês de todo. Já só falam inglês e já não usam casacos de peles, só sapatos compensados. Mas é aquele grupo de oitocentas pessoas, muito fechado, semiprofissional e que está em todas as representações, uma espécie de festival permanente. A ideologia é a da festa. «Ai que grande festa! Baile depois da estreia!» Parece que estamos no século XIX. No século XIX de uma sociedade muito reduzida. A Lisboa queirosiana. Não sei se com adultérios sequer.... Mas incestuosa de certeza.

Essa transformação que viste acontecer, essencialmente nos anos 80, primeiro com a estatização, a normativização, a democratização do teatro, depois começas a ter o Estado, que...

... que incentiva...

... que incentiva, mas, na verdade, é um paradoxo porque continua a subscrever essa missão de permitir o acesso à cultura, mas diminuindo os meios para que isso aconteça. $O$ modelo existe para servir a mesma ideia que vem de Garrett. $O$ Estado tem de continuar a incentivar, a vigiar o teatro que se faz, a educar...

Claro! Claro!

Como vês o que entretanto foi acontecendo? Não faz sentido que exista um teatro nacional, e ao mesmo tempo o Estado queira que ele continue e que não lhe custe nada. Define a sua missão, regulamentação e aquelas coisas todas pedidas pelos concursos...

Mas sem gastar dinheiro... Agora os modos de financiamento são muito engraçados. Há uma associação, a GDA [Gestão dos Direitos dos Artistas], dos direitos de autor, que faz um concurso de apoio a projectos de jovens. Quem é o júri? Soube hoje. É extraordinário! Todos ou quase todos os directores de teatros oficiais. Estão ali a ver se gastam menos 
dinheiro do seu orçamento a acolher alguns espectáculos. Então, para que é que é um concurso? Para os artistas? Ou para as instituições? E só não estavam lá representantes da Culturgest, honra lhes seja feita, ao Miguel Lobo Antunes e ao Francisco Frazão. É muito ambígua agora a relação com as instituições que acabam por beneficiar da miséria em que vivem os «independentes»... Uma co-produção do Teatro D. Maria com uma empresa como a nossa é subsidiada de duas maneiras. É subsidiada, porque os AU levam dinheiro da Direcção-Geral das Artes (DGA) e é subsidiada porque os AU vão trabalhar mais barato ou vão oferecer mão-de-obra barata ao Teatro Nacional. Ganho mil euros por mês. Se fosse contratado pelo Teatro Nacional ganhava mais, mas, como vou ao Teatro Nacional fazer uma peça enquanto estou a fazer outra aqui, ganho mil euros pela peça de lá e nada pela peça daqui. Isto significa que a DGA, cujo objectivo é apoiar a iniciativa não estatal, está realmente a apoiar directa e indirectamente a iniciativa estatal. É um caso turvo.

Apesar da política liberal, parece continuar a ser o Estado e as suas instituições a intervirem, na própria configuração do sistema teatral...

Pois, mas, por exemplo, para a GDA é importante que os espectáculos apoiados por eles sejam reconhecidos pelas entidades estatais, e sejam feitos em salas nobres e não num barracão qualquer. É um negócio que interessa a toda a gente. Mas é um negócio! E silencioso.

A cidade, como já tens escrito, não tem evoluído propriamente no sentido de fazer que as pessoas estejam confortáveis nela e queiram ir ao teatro.

A cidade está muito difícil...

\section{Os cinemas vão para as periferias...}

Estão todos nas auto-estradas. No fundo, a grande cidade burguesa do século XIX desapareceu. O Grandella e o Chiado já não são grandes armazéns. Tudo aquilo que fazia a nossa ideia da grande cidade, que vem do Balzac ou do Zola, já não existe, pelo contrário, voltámos àquilo que existia antes da grande cidade, que são as aldeias aglomeradas. Noutro dia estive em Alcântara. «Ah, que encanto! Que cidade maravilhosa que está ali!», mas é Alcântara, às portas da cidade. Parece que em Chelas 
também está uma atmosfera engraçada, enquanto aqui no centro é um deserto lindinho e horroroso...

Um sítio onde não se pode habitar e assim voltamos aos públicos. Onde estão os públicos aqui na cidade e no país?

Há teatros onde não há pessoas. E agora construíram imensas salas onde não existe público. Os autarcas acharam necessário ter um teatro ou um cineteatro enorme! Mas gigantescos! Maiores que as cidades. $\mathrm{O}$ que é que eles querem pôr lá? O de Caldas da Rainha tem um palco maior do que o do CCB. É fantástico! Só que devia era estar em Lisboa!

Mas não conseguem gerir os espaços porque não têm população sequer para encher...

Não, não existe.

\section{A não ser através das digressões. Como vocês fazem, não é?}

Vamos a muitos sítios e as salas enchem mais ou menos...

\section{Mas é por um dia...}

Sim, é por um dia. Mas, se, por acaso, nesse dia há outra coisa, como futebol, o Tony Carreira, está vazio, porque quase não há trabalho com o público. Se for o acontecimento da semana, OK! Uma vez fomos a um teatro fora de Lisboa num dia 3 ou 4 e a sala estava fraca. Porquê? Porque a Agenda Cultural local ainda não tinha saído.

O que gostarias muito de fazer que não fizeste ainda? Há coisas que já não são oportunas ou que não vêm a tempo? Como é que relacionas isto com o teu filme Ainda não Acabámos e o paradoxo que parece existir nele: uma visão nostálgica e ao mesmo tempo o desafio do título e da figura do jovem actor na cidade?

Aquilo que gostaria de fazer, nestes últimos quatro, cinco anos de vida activa que tenho pela frente, era ter um teatro. Não é esta salinha. Ter um teatro com programação regular, com peças e não só com performances. Um espaço onde os vários actores que fui encontrando na minha vida o João Pedro Mamede, o Miguel Borges, o Manuel Wiborg... - pudessem ter um lugar e a autonomia de criação. Queria voltar, não a um hangar sujo como era A Capital, mas a um teatro onde pudesse dar-lhes voz e futuro. A coisa que mais me encanita é que, e ainda não acabámos, não 
deixei futuro a ninguém. Não há herança possível, nem há instrumentos que eu esteja a deixar a outras pessoas. Estou só a deixar a minha tristeza por ir-me embora, mas não instrumentos de trabalho reais, que era aquilo que pensei que poderia fazer ao criar os $\mathrm{AU}$. Neste momento estou a desfazer-me de quase todos os livros que tenho. Dá-los a sítios certos. É um grande alívio. «Olha, os meus livros de cinema estão todos na Cinemateca. Eh pá! Que bom!» Servem para outra coisa que não estarem aqui a encherem-se de pó. Os meus livros de política estão na Fundação [Mário] Soares. Servem para coisas. Com o teatro isso não acontece. Não sei quem é que pode pegar naquilo que aprendi fazendo e gostava que isto servisse para alguma coisa, mas não tenho a certeza de que sirva.

Mas... na verdade foi o que fizeste nestes últimos vinte, vinte e cinco anos...

Não sei, não sei...

Compreendo que é totalmente diferente ter um espaço, porque o espaço é o que possibilita fazer muitas coisas - e não apenas espectáculos -, conviver, trocar ideias e projectos, discutir. Era esse o espaço da cidade que tu conhecias em jovem, o espaço do centro de artes n'A Capital e que poderia ser o teu espaço, mas, ao mesmo tempo, existe o fazer, o estar a fazer, o saber fazer e o encontrar maneiras de fazer e de desafiar as dificuldades. Isso, conseguiste passar-lhes?

Cada vez menos. Se tenho peças com três actores e depois a próxima é com outros três... A quem estou realmente a passar, que encontros se estabelecem? Nos primeiros espectáculos dos AU, entravam como actores - e são só alguns - o Bruno Bravo, o Jorge Andrade, a Sílvia Filipe, a Joana Bárcia, o Joaquim Horta, o Miguel Pereira, o João Meireles, o Tiago Rodrigues, o Miguel Borges, o António Simão... Num elenco de vinte, ou vinte e cinco, é natural que haja quem queira pegar naquilo que foi ali feito. Muitos destes vieram a construir espectáculos próprios ou a dirigir estruturas. Num elenco de três, a que se segue outra peça com outro elenco de três... O que é que fica? Percebi que há pessoas que estão interessadas em levarem o que puderem da experiência comigo, mas é um contacto muitíssimo mais reduzido do que aquilo que eu teria gostado. 
Não está na tua ideia uma companhia, ou está? O espaço está associado a uma companhia mais regular que permita uma continuidade mais estável?

Está! Aquilo que ambiciono e não conseguimos ter são contratos de trabalho com $60 \%$ das pessoas que aqui estão. Temos só com $40 \%$ e não conseguimos ter com mais. Também não se justifica ter com mais. Contratos de três meses não valem muito a pena. E desejava ter as pessoas a trabalhar cada vez em mais coisas, mas cada vez tenho menos pessoas que estão interessadas em trabalhar além do seu trabalho como actor. Isso significa que esta casa não está a inspirar. A nossa vida quotidiana não está a inspirar as pessoas, que não se agregam a nós suficientemente para eles quererem... «Olha, eu hoje fico a cortar bilhetes...» Coisa que fiz desde que nasci. A nossa vida, agora, não permite isso. Os actores querem ser actores, os encenadores querem ser encenadores. Aquilo de que gosto é a tal coisa do 25 de Abril, mas o 25 de Novembro está sempre a ganhar. 